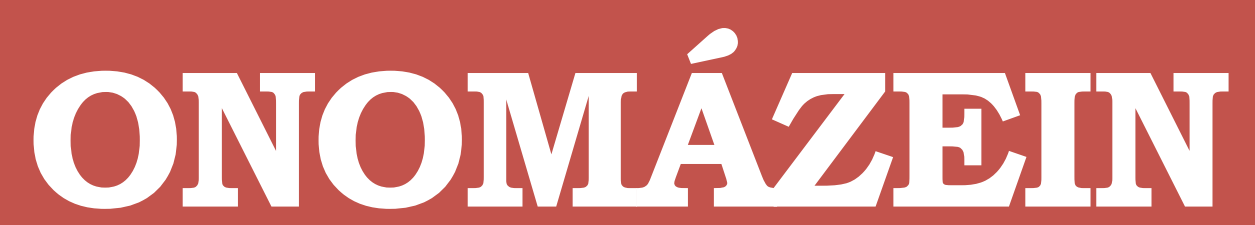

Journal of linguistics, philology and translation

\title{
A bibliometric study of co-authorship in Translation Studies
}

\author{
Sara Rovira-Esteva \\ Universitat Autònoma de Barcelona \\ España
}

\section{Javier Franco Aixelá}

Universidad de Alicante

España

\section{Christian Olalla-Soler ${ }^{1}$}

Universitat Autònoma de Barcelona

España

ONOMÁZEIN 47 (March 2020): 158-194

DOI: 10.7764/onomazein.47.09

ISSN: 0718-5758

\section{(c) $($ i) $\ominus$}

Sara Rovira-Esteva:Departament de Traducció i d'Intepretació i Estudis de l'Àsia Oriental, Transmedia Catalonia, Universitat Autònoma de Barcelona, Spain. | E-mail: sara.rovira@uab.cat

Javier Franco Aixelá:Department of Translation and Interpreting, University of Alicante, Spain.

Christian Olalla-Soler:Departament de Traducció i d'Intepretació i Estudis de l'Àsia Oriental, PACTE, Universitat Autònoma de Barcelona, Spain. 


\section{Abstract}

The main aims of this article are, on the one hand, to gain a better understanding of co-authorship practices in Translation Studies (TS) by examining how they have evolved over time and, on the other, to find out whether there is a citation advantage for co-authored works. Most of the data used for this study have been retrieved from BITRA (Bibliography of Interpreting and Translation), containing over 69,000 TS records. The analysis covering 54 years has focused on parameters including the percentage of co-authored documents versus single-authored, co-authored contributions by document type, evolution of co-authorship over time, mean number of authors per contribution, citations of co-authored vs. single-authored documents, or the ratio of international cooperation in TS. In order to complement the bibliometric analysis, we also weigh up the advantages and disadvantages of co-authorship taking a more qualitative approach. Our data yield the following interesting results. Firstly, the number of co-authored documents and the number of citations accrued by co-authored documents are on the increase. Secondly, there is a slight co-authorship citation advantage in the case of journal articles. Thirdly, the average number of authors is nowadays higher in TS as compared with other disciplines in Humanities. Fourthly, the ratio of international collaboration is rather poor, below 10\%. Our findings represent an initial insight into the evolution and current situation of co-authorship in TS, and hopefully it might prove inspiring and a valuable starting point not only for future research, but also for research assessment policies that should be permeable to new trends in publication patterns in TS.

Keywords: bibliometrics; citation advantage; co-authorship; impact; Translation Studies.

1 The three authors are equally responsible for the contents of this essay. Sara Rovira-Esteva directed the writing and coordination of information, Javier Franco was especially responsible for obtaining and analyzing the data retrieved from BITRA, while Christian Olalla-Soler was responsible for statistical data analysis. However, the authors revised and complemented each other's work via a dialectic process. 


\section{Introduction}

Bibliometrics, almost unheard of in Translation Studies (TS) a decade ago, offers a wide range of possible approaches to studying academic publications and opens up new perspectives for self-understanding and self-diagnosis within disciplines. However, in recent years, there has been an increasing number of bibliometric publications targeted at categorizing and explaining different aspects of the historical development and current state of affairs in TS. Current studies either adopt general approaches (Grbić and Pöllabauer, 2008c; Grbić, 2013; Franco Aixelá, 2013; Van Doorslaer, 2014 and 2016; Dong and Chen, 2015; Gile, 2015; Rovira-Esteva et al., 2015; Liang and Xu, 2016), or focus on specific countries or topics, for example Candel-Mora and Vargas Sierra (2013)-corpus linguistics; Esqueda and De Jesus (2015)-scientific and technical translation in Brazilian journals; Franco Aixelá (2012) - TS journals in Spain; Wang (2013 and 2015) and Xu (2015)-research on interpreting in China, or Nouraey and Karimnia (2015)-Translation Studies in Iran.

TS scholars are commonly assessed within the broader fields of Linguistics or Humanities. However, as any other discipline, TS have their own scholarly practices, and ignoring or overlooking the idiosyncratic nature of TS research often leads to unfair assessment. To better understand and establish benchmarks for our discipline and field of research, we first need to carry out more and larger-scale bibliometric studies to obtain objective data that helps us determine what can be considered "normal" or average in our discipline. To date, TS bibliometric approaches have mainly focused on the presentation of existing TS bibliographical databases, impact in terms of citations, Google Scholar h5-index or the most influential scholars. However, except for the works of Grbić and Pöllabauer (2008a and 2008b), who researched co-authorship and authorship networks based on a case study of a highly productive author, on the one hand, and within the context of community interpreting in German-speaking countries, on the other, the literature on joint authorship practices in TS as a whole is almost non-existent. Needless to say, it has never been approached in terms of impact.

Some authors (see Franco Aixelá, 2010a, 2010b and 2013; Franco Aixelá and Rovira-Esteva, 2015) have already questioned the traditional concept of impact taking TS as a case study and illustrating with numerous examples why impact in the form of citation counting should always be discipline-weighted and even (sub)topic-relative. Apart from the intrinsic quality of each study, there is a broad gamut of factors that can contribute to the impact of a publication in terms of citations. Franco Aixelá and Rovira-Esteva (2015), for example, showed that impact also has much to do with the topic or popularity of the object of study, the subgenre (e.g., case study vs. handbook), distribution potential (commercial publishers vs. small universities), format and the language used (English vs. others in a very graded series). While the above-mentioned variables to a greater or lesser extent have already caught the attention of researchers in TS, other aspects are still overlooked, such as authorship or the role of open access. 
Funding agencies foster interdisciplinary-and consequently collaborative-networks and research. Yet, paradoxically, those contributions considered to have more than the average number of authors in the field, or multi-authored articles not dealing with complex enough topics, are given less credit by some universities or research assessment bodies in some countries (Rovira-Esteva and Orero, 2011 and 2012; Joseph, 2014; Pérez-Paredes, 2016)². Cronin and Overfelt (1994: 61) mention three different approaches to allocating citational credit in the case of multi-authored works: (i) straight counting (only first author receives credit), (ii) whole counting (all authors receive full credit), and (iii) adjusted counting (fractions are awarded to each co-author) ${ }^{3}$. Therefore, despite the fact that research is often carried out in teams, many scholars within TS believe they would do better to publish on their own if they are to succeed in evaluation exercises.

Co-authorship is, thus, more often than not problematic when academic publications are subjected to an external evaluation process. As Joseph (2014: 8) states, "the prevailing practice of credit splitting for multi-authored papers seems outdated and out of sync with current authorship patterns". Making objective data on current practices available should be mandatory and contrasted with related disciplines, so that we have a reliable reference point about what should be considered the norm in TS as regards the number of authors, author ordering, as well as collaboration practices in general. Only then would we be in a position to avoid penalizing collaboration practices by applying adjusted counting by default.

With this aim in mind, in this article we attempt to answer five research questions. Firstly, do TS have their own ecosystem as far as co-authorship practices are concerned? Secondly, is there a trend favoring co-authorship? Thirdly, does co-authorship vary in relation to document type or journal? Fourthly, does co-authorship have a citation advantage in TS? Fifthly, which is the rate of international collaboration of TS scholars? Finally, does co-authorship offer any advantage for the researcher beyond citation counts?

The following sections present the evolution of co-authorship in TS, from a quantitative perspective, and then again from a qualitative viewpoint, pointing out its drawbacks and advantages. The final section summarizes the main conclusions, underlines the limitations of this study and sets out lines for possible future research.

2 TS scholars in different countries, including Spain, Poland and Italy, report co-authorship in the Humanities is penalized by research assessment agencies, while it is not so in Sweden or the United Kingdom. Actually, the Spanish research assessment agency (CNEAI), for instance, explicitly states in its assessment criteria for the Linguistics panel (under which TS scholars are assessed) that authorship is expected to be individual. Co-authorship is only accepted if either the research topic or the methodological approach justify the need for more authors. Nevertheless, to obtain a positive research assessment authorship must not exceed the norm within the discipline (ANECA, 2015: 27).

3 For other approaches to co-authorship credit assignment, see Joseph (2014: 6-8). 


\section{Data and methods}

\subsection{Existing databases as sources of information}

Gathering empirical data on the object of study enables us to make informed decisions about which is the best (personal) strategy to follow in this respect. The largest commercial, mainly experimental-science-oriented, citation databases such as Web of Science (WoS - JCR) or Scopus (SJR) present an inadequate coverage of TS publications. In 2017 only $8.5 \%$ and $27 \%$ of TS current journals were indexed in the JCR and SJR, respectively, whereas books were virtually non-existent ${ }^{4}$. Therefore, data have been retrieved from different sources, such as World of Science (WoS) Journal Citation Reports (JCR), Co-author Index, Google Scholar Metrics (GSM), SCOPUS SCImago Journal \& Country Rank (SJR), RETI and the BITRA database (Franco Aixelá, 2001-2018). Since the two most worldwide used citation databases are not representative of research carried out in our field, the data used in this present research has been mainly extracted from BITRA for the following five reasons.

Firstly, it is the most comprehensive international database with bibliographic data for scholarly TS publications, including over 69,000 records as of April 2017.

Secondly, using a bibliographical database that transcends journal articles, including all types of TS documents, as well as publications not written in English that are seldom covered by most prestigious traditional indexes, represents a major advantage for bibliometric research in our field.

Thirdly, evaluations based on citation analyses in the social sciences and humanities require longitudinal data to better reflect the long-term use in their literatures (Huang and Chang, 2008: 1,826). BITRA allows us to carry out a large-scale study on citation patterns of TS academic literature contingent on authorship type covering a lengthy time span (1961-2015).

Fourthly, BITRA has already collected citation data from over $10 \%$ of its entries. This relatively new feature, with almost 100,000 citations already assigned to the corresponding cited documents ${ }^{5}$, is a good solution for overcoming the limits of existing data sources and opens up new research perspectives, since it allows for systematic research into data combinations such as co-authorship and impact, which is one of our main concerns here.

Last but not least, there is a consensus in the literature that citation counts of publications from different fields should not be directly compared with each other. Consequently,

4 Data obtained from RETI (see Biblioteca d'Humanitats. Universitat Autònoma de Barcelona, 2018)

5 For further information about the sample, see http://dti.ua.es/en/bitra/impact.html. 
we need to normalize citation impact indicators, and a key issue in the calculation of these normalized citation impact indicators is the way in which the concept of a scientific field is operationalized. One of the possible ways this can be undertaken is through predefined database fields (Wouters et al., 2015: v). BITRA is a comprehensive database containing structured information on the various types of output in TS. Using a TS-specific database solves the problem of the delineation of an appropriate set of publications for use as a comparison or reference set. We are thus carrying out a form of source-normalization i.e., we choose to eliminate the underlying discipline-related difference in the citation behavior of the citing authors. For further information about the normalization of our data, please refer to subsection 2.3.

However, whenever possible, efforts have been made to triangulate and provide more comprehensive data by performing complementary searches in all the other aforementioned databases when applicable ${ }^{6}$.

\subsection{From BITRA to a comprehensive ad hoc database for the analysis of cita- tion patterns in Translation Studies}

In April 2017, BITRA contained 69,056 documents (many of them previous to our period of study or without citations). All document types but PhD theses and journal special issues were selected, namely books, book chapters in edited volumes, and journal articles. To perform our analysis, all documents included in BITRA were exported and converted into a new database. In order to work with a homogeneous sample, a period of analysis ranging from 1961 to 2015 (after which only a small percentage of the citations has been detected as yet) was established and documents published before 1961 and after 2015 were deleted from the database. Once the database was built, it was checked to find and correct errors. After the cleaning process, our database contained 23,632 cited documents and 40,608 non-cited documents $(64,240$ documents altogether). The percentage of non-cited documents $(65.24 \%)$ is very outstanding but usual in bibliometrics (De Bellis, 2009: 85).

With our database, the type of authorship was analysed in relation to the publication format (book, article, and book chapter) and publication period (1961-1980, 1981-2000, and 2001-2015).

6 Translation Studies Bibliography (TSB) was also initially included as a source; unfortunately, its search engine did not enable us to retrieve data about co-authorship.

7 Journal special issues and PhD theses were excluded from our study because they are by default co-authored and single-authored document types, respectively. However, the journal articles included in these special issues did form part of the analysis. 


\subsection{Data preparation and normalization}

Each publication type or format presents differences in the density of documents published and number of citations detected in each period. This could affect the analysis and, as De Bellis (2009: 116) observes, "[a] corrective factor is required if citation rates are to be adjusted for changes in the size for the citing population (...)." Thus, we needed to normalize the citation count for each publication to correct possible bias caused by the publication type and publication year in our analysis. To do so, we calculated the average normalized citation score (Waltman, 2016) for each document in relation to its publication type and publication year. The mean and standard deviation for the documents of each type of authorship and for each publication type and period were computed.

Distribution of the number of authors for all documents and for co-authored documents was checked using $Q-Q$ plots and the Shapiro-Wilk test. Because of the nature of the data that were being analysed, the normality assumption could not be met $^{8}$. Transforming our data to meet this assumption could distort the interpretation of the results. Thus, all comparisons between publication periods were carried out with the Kruskal-Wallis test as an omnibus test and the Mann-Whitney's $U$ test for the post-hoc tests with the Bonferroni correction. Effect sizes are provided for all tests. When comparing between authorship types in each publication period, the Mann-Whitney's $U$ test was employed. We set the alpha level at $5 \%$.

\section{Co-authorship in Translation Studies: evolution and current situation}

\subsection{Co-authorship as a rising phenomenon in the Humanities and Social Sciences}

While collaborative authorship is commonplace in the sciences, it is less so in the Humanities. Joseph (2014) reports the following percentages of co-authorship: $70 \%$ in Biology, $78 \%$ in the field of Agriculture, $83 \%$ in Chemistry, and $90 \%$ in Astronomy, to give just a few examples. Whereas a recent study by Kuld and O'Hagan (2018) found that by $201475 \%$ of papers published in top-ranked economics journals were co-authored.

According to Moody (2004) in the Humanities and Literature, co-authorship is a marginal phenomenon. However, Larivière et al. (2015: 1330-1) claim that from 1900 onwards, co-authorship, inter-institutional collaboration, and international collaboration have been increasing in the Humanities. More specifically, they state that single-authored papers decreased in the

8 Non-normal distribution is the norm in bibliometric studies, where productivity and impact are "markedly skewed, conforming to a hyperbolic pattern" (De Bellis, 2009: 77; cf. also De Bellis, 2009: 84-88 and 209). 
Social Sciences and Humanities from 97\% in 1900 to 38\% in 2001, which means that the majority of contemporary papers are the result of some sort of collaboration.

The figures given by Larivière et al. (2015) are higher than those given by the online application Co-author Index (Delgado et al., 2016), according to which only $16.3 \%$ of articles in Linguistics during the 1999-2015 period were co-authored.

While it is safe to say that TS cannot boast of a tradition of collaborative authorship, ways of conducting research evolve in all disciplines, and TS is no exception. To be able to describe current research practices and establish well-informed assessment criteria regarding collaborative authorship, we first need a clear idea of how it has evolved and the current state of affairs. Thus, the next sections look at co-authorship in relation to its evolution over the years, document type, and the average number of authors found in co-authored documents.

\subsection{Evolution of co-authorship in TS}

The average percentage of co-authorship as far as TS journals are concerned was $21 \%$ according to Co-author Index, which clearly shows that co-authorship is more common in TS than in the broader field of Linguistics. However, data from this online resource has to be treated with some caution: first, the time span covered is relatively short (16 years); second, it only includes 12 TS journals and no selection criteria are given; and last but not least, it is not systematic in the number of years and articles mined for each journal9. So, the data yielded by this search engine cannot be considered conclusive.

According to BITRA's data, from its 64,240 entries registered for our whole period (19612015) at the time of writing this article, only 10,266 (16\%) are co-authored contributions ${ }^{10}$.

The thousands of results yielded by BITRA (see figure 1) show a spectacular increase in the percentage of co-authored TS documents over time (scarcely $7.4 \%$ until 1970, but rising to as much as $25.1 \%$ in the 21 st century).

9 TS journals included and years covered for each one are: 1611: Revista de Historia de la Traducción (2007-2015), Babel: International Journal of Translation (2011-2015), Estudios de Traducción (20112015), Hermeneus (1999-2014), Interpreter and Translator Trainer (2007-2015), MonTI (2009-2015), Quaderns: Revista de Traducció (1999-2015), Hikma (2002-2013), Livius (1999), Perspectives: Studies in Translatology (1999-2015), Sendebar (1999-2015), and Target (2008-2015).

10 When a contribution has "Various authors" in the "author" field, this means that it was published without any specific authorship. These cases have been treated as co-authored contributions in this study, since a revision of the sub-corpus clearly shows that these "anonymous" works systematically consist of conference proceedings and corporate or institutional publications. 


\section{FIGURE 1}

Evolution of co-authored TS works for the whole period of analysis (1961-2015). Source: BITRA (April 2017)

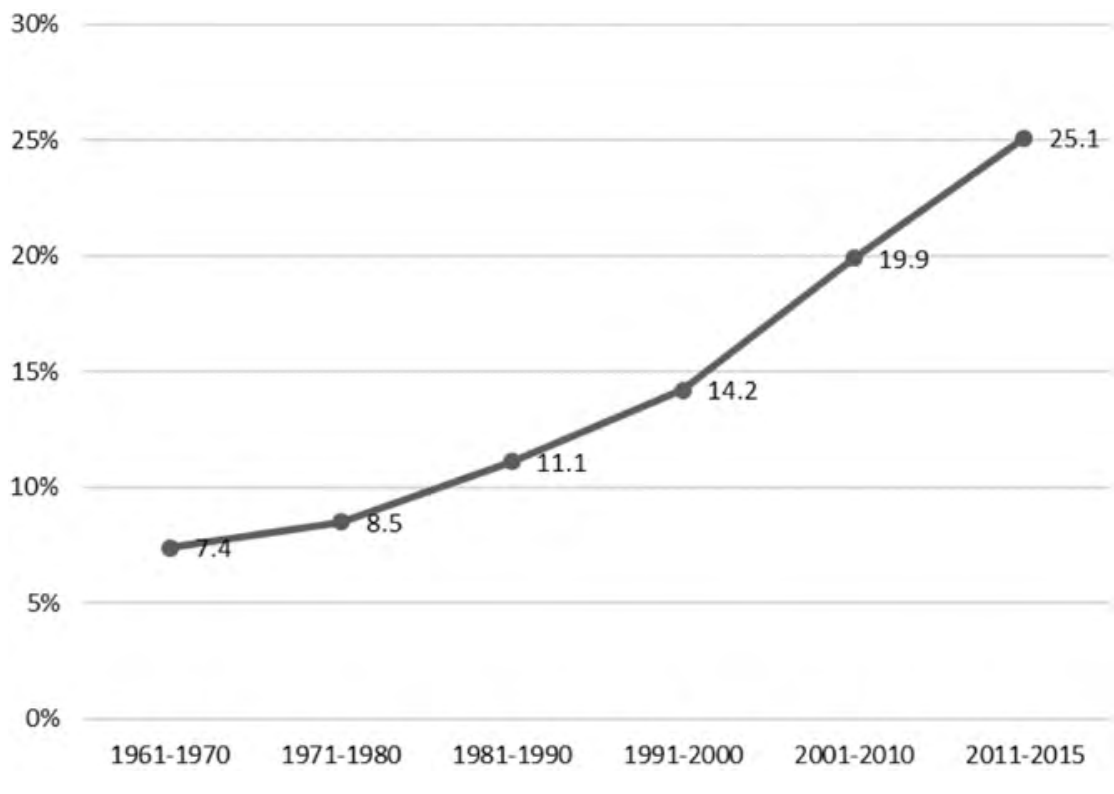

In order to determine whether this increase in co-authorship has stabilized or is likely to continue, data for the 21st century were analyzed in three-year blocks (see figure 2). Results show that there is a steady increase towards more co-authorship, reaching $26.5 \%$ in the last period analyzed (2013-2015).

\section{FIGURE 2}

Evolution of TS co-authored works in the 21st century. Source: BITRA (April 2017)

$30 \%$

$25 \%$

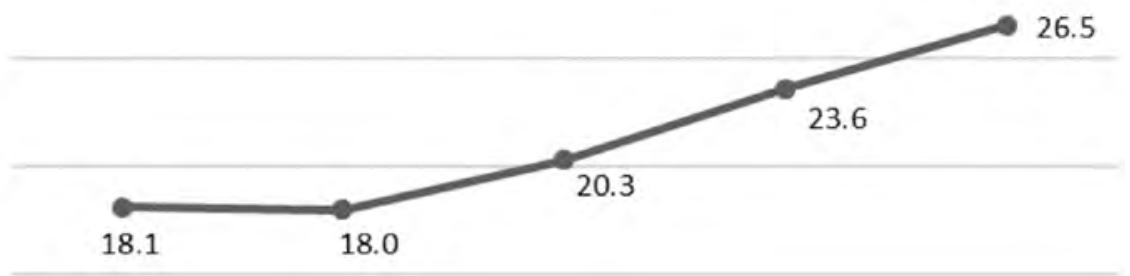

$15 \%$

$10 \%$

$5 \%$

$0 \%$

$2001-2003 \quad 2004-2006 \quad 2007-2009 \quad 2010-2012 \quad 2013-2015$




\subsection{Co-authorship in TS in relation to document type}

If we look at co-authored publications in relation to document type, those which rank highest are books (27.8\%). Journal articles (11.2\%) and book chapters (9.0\%) are the document types with a lower percentage of co-authorship-see figure 3. This means that books are twice more frequently co-authored compared with the other two types of publications. A feasible explanation for the high percentage of co-authored books is that writing a book normally implies a greater effort than a chapter or an article, and this encourages co-authorship. It should also be noted that conference proceedings tend to be published as books and usually have more than one editor.

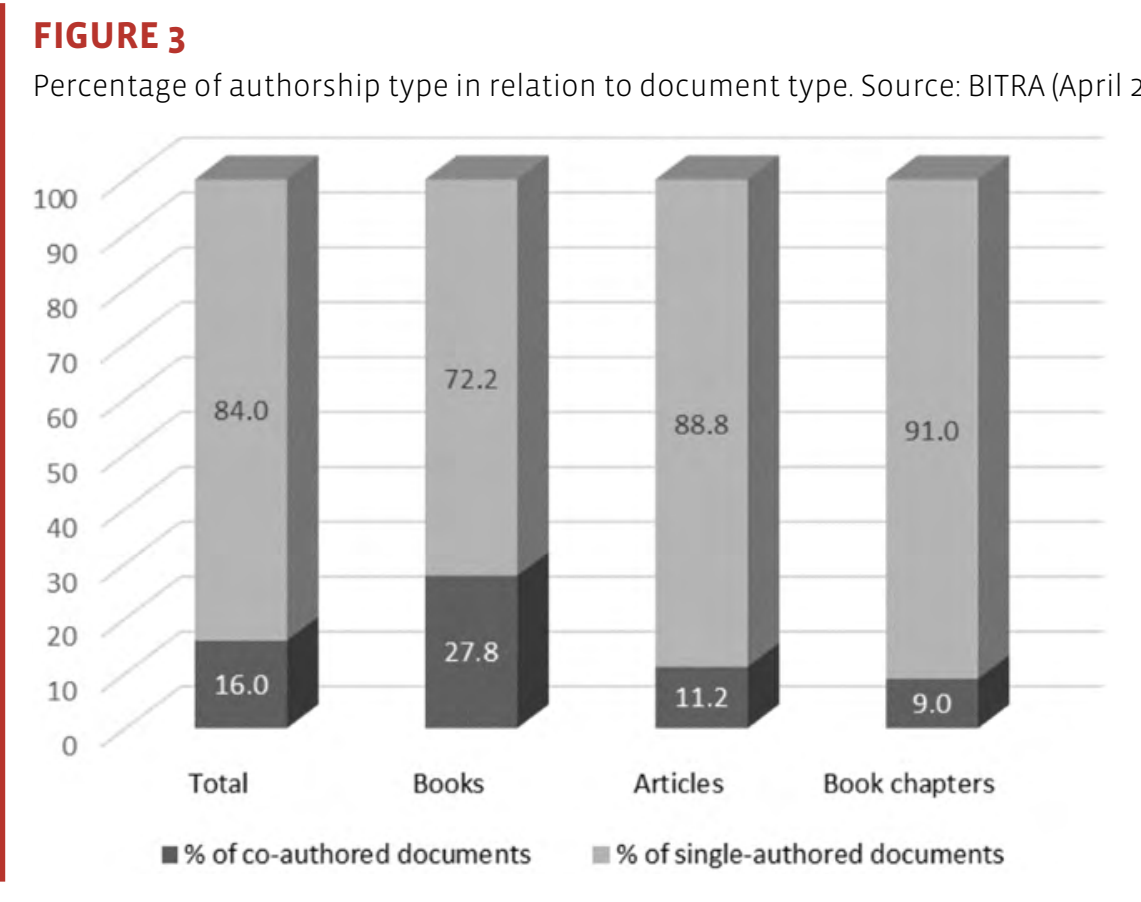

\subsection{Average number of authors in Translation Studies}

We do not know what number of authors is considered appropriate in TS by institutional evaluators. According to Larivière et al. (2006: 5), the mean number of authors in the Natural Sciences, Social Sciences and Humanities is 1.72, 1.30 and 1.03, respectively, while Harzing (2010) affirms that Social Sciences and Humanities articles have 1.6 authors on average. Pérez-Paredes (2016: 8) analyzed 2013's Google Scholar Metrics top 20 journals in the field of Applied Linguistics according to their h5-index, and found that the average number of authors in the areas of Language and Linguistics, Foreign Language Learning and English Language and Literature were 2.2, 2.2 and 1.4, respectively. Therefore, he claims that single-authored papers are not the norm in the case of highest impact journals in these disciplines. 
The average number of authors in Linguistics for the 1999-2015 period according to the Co-author Index is 1.18 in Spanish journals and 1.86 in international journals ${ }^{11}$.

Rovira-Esteva and Orero (2011: 238-39) reviewed a sample of 500 articles from Thompson Reuters' indexed TS journals covering a three-year period (2007-2009) and concluded that the average number of authors was 1.18 .

Turning to TS journals included in Co-author Index, the average number according to this online application is 1.31 (see figure 4 for the average number of authors of TS journals for the 1999-2015 period).

\section{FIGURE 4}

Average number of authors of TS journals for the period 1999-2015. Source: Delgado et al. (2016)

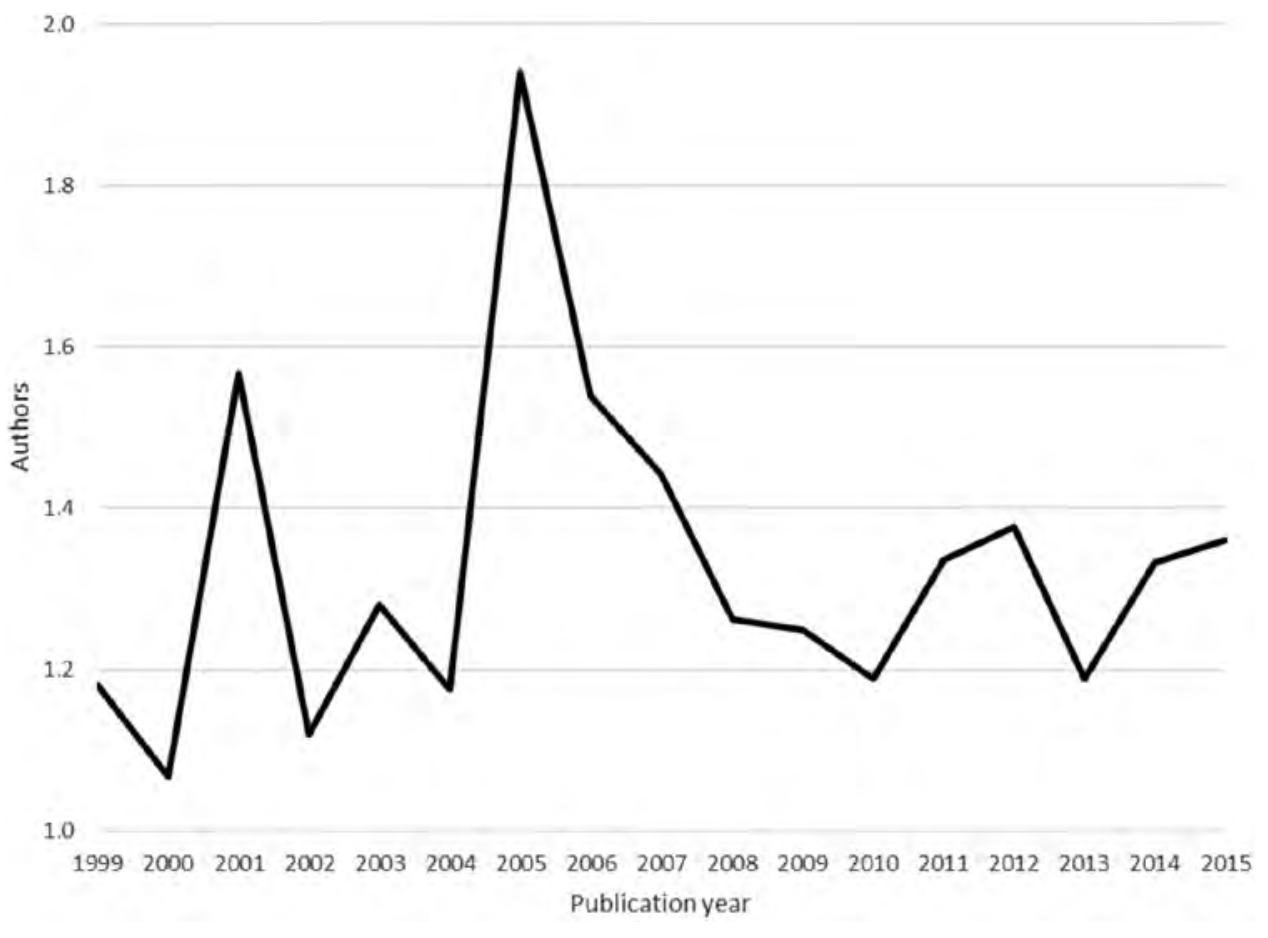

However, there are notable differences between journals (see figure 5). While the average in some is very close to one (1611: Revista de Historia de la Traducción, Estudios de Traduc-

11 Co-author Index does not define what it is meant by "international journals". However, since this tool has been developed by a Spanish research group, and their webpage is only in Spanish, it can be implicitly understood that they refer to those journals not based in Spain. It should also be noted that 2015 is the last year available. 
ción, Hikma, and Quaderns: Revista de Traducció), the average for Target, The Interpreter and Translator Trainer, and Perspectives: Studies in Translatology is 1.41, 1.62 and 1.86, respectively. Therefore, in the case of TS, there also seems to be a higher percentage of co-authored articles in internationally-oriented journals.

\section{FIGURE 5}

Average number of authors of TS journals for the 1999-2015 period. Source: Delgado et al. (2016)

6
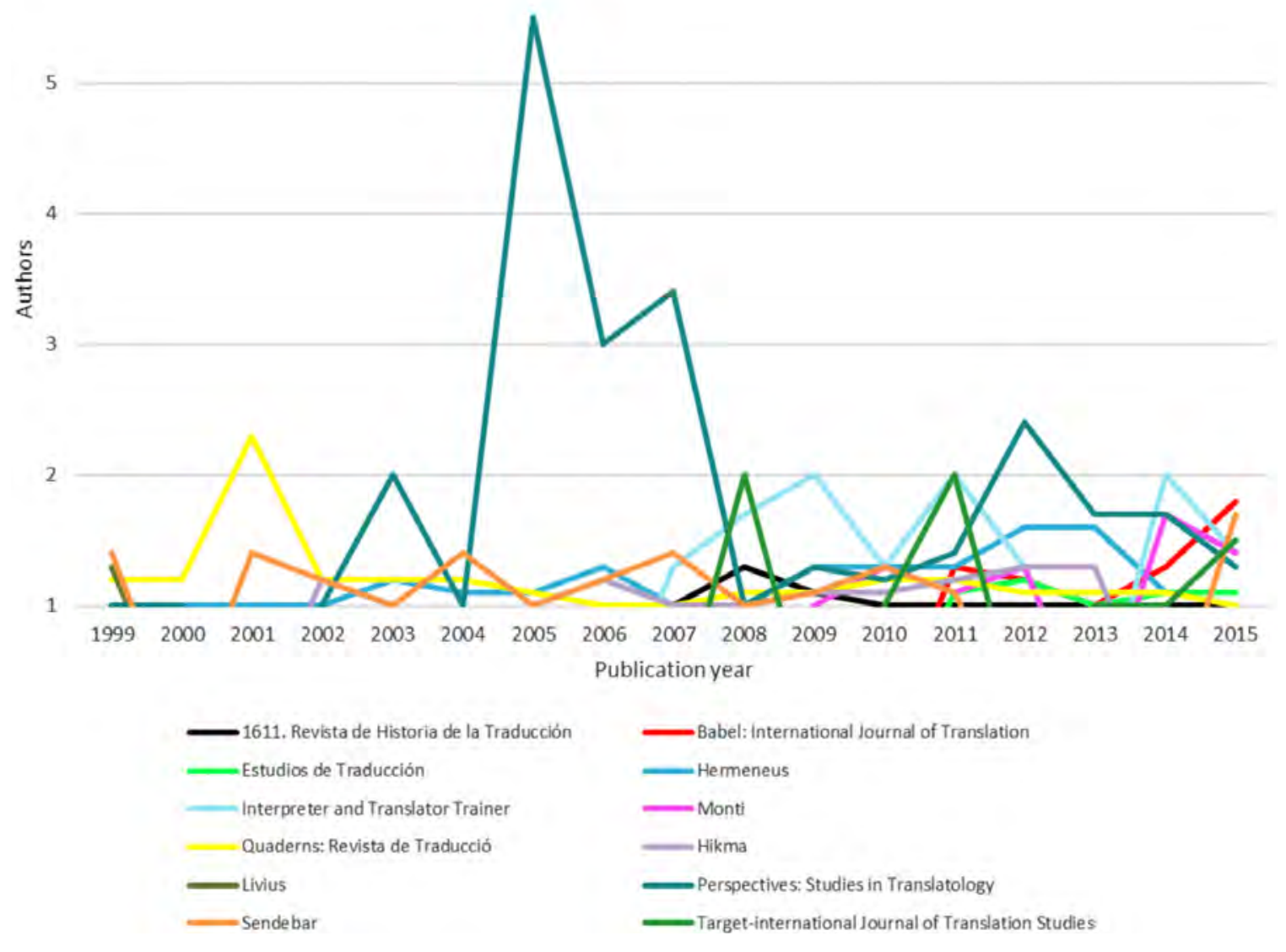

In any case, since all the above-mentioned studies feature rather small samples and do not include all types of documents, results cannot be taken as a reference for the discipline as a whole.

In BITRA, the average number of authors in TS publications across the entire time period covered (1961-2015) is 1.21. However, it is interesting to note that this mean has increased over time and it stands at 1.34 in the 21st century (see table 1 ). If we restrict our analysis only to co-authored documents, we find that the average number of authors in the 21st century is 2.59 . 


\section{TABLE 1}

Evolution of the mean number of authors in TS. Source: BITRA (April 2017)

\begin{tabular}{lllll} 
& $\mathbf{1 9 6 1 - 1 9 8 0}$ & $\mathbf{1 9 8 1 - 2 0 0 0}$ & $\mathbf{2 0 0 1 - 2 0 1 5}$ & MEAN \\
All documents & $1.10(\mathrm{Mdn}=$ & $1.20(\mathrm{Mdn}=$ & $1.34(\mathrm{Mdn}=$ & $1.21(\mathrm{Mdn}=$ \\
& $1 ; \mathrm{SD}=0.43)$ & $1 ; \mathrm{SD}=0.59)$ & $1 ; \mathrm{SD}=0.74)$ & $1 ; \mathrm{SD}=0.59)$ \\
\hline Co-authored & $2.36(\mathrm{Mdn}=$ & $2.43(\mathrm{Mdn}=$ & $2.59(\mathrm{Mdn}=$ & $2.46(\mathrm{Mdn}=$ \\
documents $^{12}$ & $2 ; \mathrm{SD}=0.82)$ & $2 ; \mathrm{SD}=0.94)$ & $2 ; \mathrm{SD}=1.22)$ & $2 ; \mathrm{SD}=0.99)$ \\
\hline
\end{tabular}

Differences were found among periods $\left(H[2]=377.003 ; p<0.001 ; \eta^{2}=0.02\right)$. A statistically significant difference was found between the first and second periods in the mean of authors for all documents $(U=8514946.5 ; p<0.001$, Bonferroni corrected, $r=0.06)$ and between the second and third one $(U=54866034.5 ; p<0.001$, Bonferroni corrected, $r=0.08)$. However, although the Kruskal-Wallis test identified statistical differences among periods regarding the number of authors in co-authored publications $\left(H[2]=20.566 ; p<0.001 ; \eta^{2}=0.001\right)$, a statistical difference was only found between the second and third periods $(U=1581750.5 ; p<0.001$, Bonferroni corrected, $r=0.06)$, and not between the first and second periods $(U=89809 ; p=0.999$, Bonferroni corrected, $r=0.02$ ). Thus, it can be concluded that the number of authors has increased significantly since 1961, although the number of authors within co-authored documents has increased in the last period only. The fact that the standard deviation increases over time means that the number of authors for each document is more variable as time goes by.

In sum, despite the fact that research in our discipline is still mainly individual or dual, it is interesting to observe that there is a clear tendency towards more collaborative writing, and that the percentage of co-authored papers is higher now than in some related disciplines. What can be considered average or "normal" in the field should take into account this tendency along with other factors, such as the research topic, the methodology, the background and nationality of the members of the team, as well as the nature of the collaboration. However, such an analysis necessarily implies a more qualitative approach to research outputs analysis and assessment.

In this connection, another variable to be taken into account is the idiosyncrasy of research teams or degree of international cooperation. Rikken (2016) went through the whole set of publications included in ResearchGate comprising all fields of knowledge and found that publications written by international teams had a median of five authors, while publications written by researchers from the same country had four, which is clearly higher than in TS. Nonetheless, further research into this topic would necessitate gathering information about authors' affiliation, which falls outside the scope of this article.

12 Those unsigned entries with the generic label "various authors" have been excluded from this estimation, since it is not possible to determine how many authors are responsible for each document. 


\section{Is there a co-authorship citation advantage in Translation Studies?}

After reviewing the literature, Leimu and Koricheva (2005: 438) pointed out that the number of authors has been shown to increase the citation rates of individual articles in some disciplines, while in other fields no such relationship has been proved. Sooryamoorthy's (2009) case study with South African publications reached the same conclusion. Since it has been shown that in some disciplines higher impact indexes are directly related to a higher number of authors per contribution, the same analysis needs to be performed with TS publications. We understand there is a co-authorship citation advantage when the average citation of co-authored articles is higher in relation to single-authored articles.

\subsection{Evolution of citation rates by authorship type in Translation Studies}

As far as we know, the effects of academic collaboration on the quality and visibility of the resulting publications has not yet been studied in TS. So, a quantitative analysis was carried out using the data obtained from 64,240 documents as mined in BITRA. At this point, it should be pointed out that BITRA excludes self-citing — which can be considered a confounder in terms of impact-, and this might be, in principle, a disadvantage for co-authored contributions, since the more authors a given publication has, the more potential self-citers there will be.

As already mentioned, entries in BITRA according to co-authorship type from 1961 to 2015 are distributed as follows: 53,974 (84\%) contributions are single-authored and 10,266 (16\%) are co-authored. After combining the authorship type variable with that for citations, several results were obtained, which are grouped in table 2 in three different roughly 20 -year periods (1961-1980, 1981-2000 and 2001-2015).

\section{TABLE 2}

Number and percentage of TS documents in citation intervals over time in relation to authorship type ${ }^{13}$

\begin{tabular}{|c|c|c|c|c|c|c|}
\hline $\begin{array}{l}\text { YEAR SPAN \& } \\
\text { AUTHORSHIP } \\
\text { TYPE }\end{array}$ & $\begin{array}{l}1961-1980 \\
\text { SINGLE- } \\
\text { AUTHORED }\end{array}$ & $\begin{array}{c}\text { 1961-1980 } \\
\text { CO- } \\
\text { AUTHORED }\end{array}$ & $\begin{array}{l}\text { 1981-2000 } \\
\text { SINGLE- } \\
\text { AUTHORED }\end{array}$ & $\begin{array}{c}\text { 1981-2000 } \\
\text { CO- } \\
\text { AUTHORED }\end{array}$ & $\begin{array}{l}\text { 2001-2015 } \\
\text { SINGLE- } \\
\text { AUTHORED }\end{array}$ & $\begin{array}{c}2001-2015 \\
\text { CO- } \\
\text { AUTHORED }\end{array}$ \\
\hline \# documents & $\begin{array}{c}3,658 \\
(92.14 \%)\end{array}$ & $\begin{array}{c}312 \\
(7.86 \%)\end{array}$ & $\begin{array}{c}21,648 \\
(86.33 \%)\end{array}$ & $\begin{array}{c}3,429 \\
(13.67 \%)\end{array}$ & $\begin{array}{c}28,668 \\
(81.46 \%)\end{array}$ & $\begin{array}{c}6,525 \\
(18.54 \%)\end{array}$ \\
\hline $\begin{array}{l}\text { \# citations } \\
\text { detected }\end{array}$ & $\begin{array}{c}8,337 \\
(91.64 \%)\end{array}$ & $\begin{array}{c}761 \\
(8.36 \%)\end{array}$ & $\begin{array}{c}40,362 \\
(84.72 \%)\end{array}$ & $\begin{array}{c}7,282 \\
(15.28 \%)\end{array}$ & $\begin{array}{c}23,639 \\
(78.44 \%)\end{array}$ & $\begin{array}{c}6,499 \\
(21.56 \%)\end{array}$ \\
\hline
\end{tabular}

13 Percentages shown in tables 2-5 have been calculated in relation to the total TS documents and citations detected in each period. 


\begin{tabular}{|c|c|c|c|c|c|c|}
\hline $\begin{array}{l}\text { Normalized } \\
\text { mean of } \\
\text { citations per } \\
\text { document }\end{array}$ & $\begin{array}{c}1.02(\mathrm{SD} \\
=1.81)\end{array}$ & $\begin{array}{c}1.02(S D \\
=1.87)\end{array}$ & $\begin{array}{c}1.02(S D \\
=2.04)\end{array}$ & $\begin{array}{c}0.96(\text { SD } \\
=1.81)\end{array}$ & $\begin{array}{c}1.01 \text { (SD } \\
=1.34)\end{array}$ & $\begin{array}{l}1.00 \text { (SD } \\
=1.30)\end{array}$ \\
\hline $\begin{array}{l}\text { o citations } \\
\text { detected }\end{array}$ & $\begin{array}{c}2,059 \\
(52.29 \%)\end{array}$ & $\begin{array}{c}179 \\
(57.37 \%)\end{array}$ & $\begin{array}{c}12,613 \\
(58.26 \%)\end{array}$ & $\begin{array}{c}2,047 \\
(59.70 \%)\end{array}$ & $\begin{array}{c}19,636 \\
(68.49 \%)\end{array}$ & $\begin{array}{c}4,074 \\
(62.44 \%)\end{array}$ \\
\hline $\begin{array}{l}\text { I citation } \\
\text { at least }\end{array}$ & $\begin{array}{c}1,599 \\
(47.71 \%)\end{array}$ & $\begin{array}{c}133 \\
(42.63 \%)\end{array}$ & $\begin{array}{c}9,035 \\
(41.74 \%)\end{array}$ & $\begin{array}{c}1,382 \\
(40.30 \%)\end{array}$ & $\begin{array}{c}9,032 \\
(31.51 \%)\end{array}$ & $\begin{array}{c}2,451 \\
(37.56 \%)\end{array}$ \\
\hline 1-9 citations & $\begin{array}{c}1,470 \\
(40.19 \%)\end{array}$ & $\begin{array}{c}120 \\
(38.46 \%)\end{array}$ & $\begin{array}{c}8,269 \\
(38.20 \%)\end{array}$ & $\begin{array}{c}1248 \\
(36.40 \%)\end{array}$ & $\begin{array}{c}8686 \\
(30.30 \%)\end{array}$ & $\begin{array}{c}2350 \\
(36.02 \%)\end{array}$ \\
\hline 10-49 citations & $\begin{array}{c}104 \\
(2.84 \%)\end{array}$ & $\begin{array}{c}11 \\
(3.53 \%)\end{array}$ & $\begin{array}{c}681 \\
(3.15 \%)\end{array}$ & $\begin{array}{c}115 \\
(3.35 \%)\end{array}$ & $\begin{array}{c}318 \\
(1.11 \%)\end{array}$ & $\begin{array}{c}95 \\
(1.46 \%)\end{array}$ \\
\hline 50-99 citations & $\begin{array}{c}12 \\
(0.33 \%)\end{array}$ & $\begin{array}{c}1 \\
(0.31 \%)\end{array}$ & $\begin{array}{c}46 \\
(0.21 \%)\end{array}$ & $\begin{array}{c}13 \\
(0.38 \%)\end{array}$ & $\begin{array}{c}23 \\
(0.08 \%)\end{array}$ & $\begin{array}{c}6 \\
(0.09 \%)\end{array}$ \\
\hline$\geq 100$ citations & $\begin{array}{c}13 \\
(0.36 \%)\end{array}$ & $\begin{array}{c}1 \\
(0.31 \%)\end{array}$ & $\begin{array}{c}39 \\
(0.18 \%)\end{array}$ & $\begin{array}{c}6 \\
(0.17 \%)\end{array}$ & $\begin{array}{c}5 \\
(0.02 \%)\end{array}$ & $\begin{array}{c}0 \\
(0.00 \%)\end{array}$ \\
\hline
\end{tabular}

Source: BITRA (April 2017)

An analysis of the percentage of single and co-authored documents in each period showed that the ratios of single-authored documents decrease over time (1961-1980: 92.14\%; 19812000: 86.33\%; 2001-2015: 81.46\%), while the percentage of co-authored documents increases (1961-1980: 7.86\%; 1981-2000: 13.67\%; 2001-2015: 18.54\%). The same pattern is found when analyzing the percentage of citations accrued by single and co-authored documents in each period: the percentage of citations accrued by single-authored documents decreases over time (1961-1980: 91.64\%; 1981-2000: 84.72\%; 2001-2015: 78.44\%), while the percentage accrued by co-authored documents increases (1961-1980: 8.36\%; 1981-2000: 15.28\%; 20012015: $21.56 \%)$.

A Kruskal-Wallis test indicated that there were statistically significant differences between periods for single-authored publications regarding the mean number of citations obtained $\left(H[2]=666.258 ; p<0.001 ; \eta^{2}=0.03\right)$. Statistically significant differences, although the size effects are rather small, were found between the $1961-1980(M=1.02 ; M d n=0.50)$ and the 1981-2000 periods $(M=1.02 ; M d n=0.47)(U=56312041.50 ; p<0.05$, Bonferroni corrected, $r=0.03)$ and between the 1981-2000 and the 2001-2015 periods $(U=56312041.50 ; p<0.001$, Bonferroni corrected, $r=0.22)$. In the case of co-authored publications, after running a Kruskal-Wallis test $\left(H[2]=174.354 ; p<0.001 ; \eta^{2}=0.04\right)$, a statistical difference regarding the mean of citations was found between the 1981-2000 and the 2001-2015 periods $(U=56312041.50 ; p<0.001$, Bonferroni corrected, $r=0.25)$, but not between the 1961-1980 and $1981-2000$ periods $(U=87387.5 ; P=0.999$, Bonferroni corrected, $r=0.05$ ). 
To sum up, as far as single-authored contributions are concerned, the mean citations per document does not vary from a descriptive perspective, although the differences between consecutive time periods were statistically significant. This could be due to the variability in the dispersion: there are more citations, but these are more dispersed, implying a higher heterogeneity in the number of citations per document. It could also be a symptom of a long citation window in TS since, as Rovira-Esteva et al. (forthcoming) concluded in their study of citation patterns in TS, the probability for a TS document to be cited for the first time many years after publication is high, especially for articles and book chapters, ranging from a likelihood of 0.3 to 0.1 from the 1 ith to the 24 th year.

Again, a Mann-Whitney U-test was run to determine if there were differences between types of authorship. Differences are significant between the mean number of citations accrued during the first period by single-authored publications $(M=1.02 ; \mathrm{Mdn}=0.50)$ as opposed to collective ones $(M=1.02 ; M d n=0.42)(U=93674 ; p<0.05, r=0.12)$. This difference is also found in the second period (single-authored $M=1.02$ and $M d n=0.47$; co-authored $M=0.96$ and $M d n$ $=0.33)(U=5826702.5 ; p<0.001, r=0.07)$. In the third period the differences were not significant $(U=11067488 ; p=0.993, r=0.01)$.

In conclusion, despite the fact that the mean citations per document in the first and second periods were found to be statistically different for single and co-authored documents, these differences were rather small and do not show a citation advantage of one kind of authorship over the other. The mean citations per document are also generally stable over time for both single and co-authored documents. However, from a descriptive perspective, we observed that, although the percentage of single-authored documents was larger both for the number of documents and number of citations detected, the percentage represented by co-authored documents and their citations increased with time.

\subsection{Evolution of citation rates in relation to document and authorship type}

The results presented in the previous section were obtained without considering differences between document types. The same calculation was then made taking this variable into account for books, articles and book chapters.

\subsubsection{Evolution of citation rates in the case of TS books}

The total number of books included in the analysis (1961-2015) is 8,417, which have accrued a total of 35,934 citations, thus giving a mean of 4.3 citations per book. It is worth noting that books are the publication type with the highest percentage of co-authored documents and also of citations detected for co-authored documents of all the publication types analyzed. Table 3 summarizes the results for books. 


\section{TABLE 3}

Number and percentage of books in citation intervals over time in relation to authorship type

\begin{tabular}{|c|c|c|c|c|c|c|}
\hline $\begin{array}{l}\text { YEAR SPAN \& } \\
\text { AUTHORSHIP } \\
\text { TYPE }\end{array}$ & $\begin{array}{l}\text { 1961-1980 } \\
\text { SINGLE- } \\
\text { AUTHORED }\end{array}$ & $\begin{array}{c}\text { 1961-1980 } \\
\text { CO- } \\
\text { AUTHORED }\end{array}$ & $\begin{array}{l}1981-2000 \\
\text { SINGLE- } \\
\text { AUTHORED }\end{array}$ & $\begin{array}{c}\text { 1981-2000 } \\
\text { CO- } \\
\text { AUTHORED }\end{array}$ & $\begin{array}{l}2001-2015 \\
\text { SINGLE- } \\
\text { AUTHORED }\end{array}$ & $\begin{array}{l}2001-2015 \\
\text { CO- } \\
\text { AUTHORED }\end{array}$ \\
\hline \# books & $\begin{array}{c}715 \\
(79.71 \%)\end{array}$ & $\begin{array}{c}182 \\
(20.29 \%)\end{array}$ & $\begin{array}{c}2,854 \\
(71.65 \%)\end{array}$ & $\begin{array}{c}1,129 \\
(28.35 \%)\end{array}$ & $\begin{array}{c}2,232 \\
(63.10 \%)\end{array}$ & $\begin{array}{c}1,305 \\
(36.90 \%)\end{array}$ \\
\hline $\begin{array}{l}\text { \# citations } \\
\text { detected }\end{array}$ & $\begin{array}{c}4,635 \\
(89.15 \%)\end{array}$ & $\begin{array}{c}564 \\
(10.85 \%)\end{array}$ & $\begin{array}{c}16,611 \\
(78.62 \%)\end{array}$ & $\begin{array}{c}4,518 \\
(21.38 \%)\end{array}$ & $\begin{array}{c}6,994 \\
(72.81 \%)\end{array}$ & $\begin{array}{c}2,612 \\
(27.19 \%)\end{array}$ \\
\hline $\begin{array}{l}\text { Normalized } \\
\text { mean of } \\
\text { citations } \\
\text { per book }\end{array}$ & $\begin{array}{c}0.99 \\
(\mathrm{SD}=2.37)\end{array}$ & $\begin{array}{c}1.09 \\
(\mathrm{SD}=2.37)\end{array}$ & $\begin{array}{c}1.04 \\
(\mathrm{SD}=2.81)\end{array}$ & $\begin{array}{c}0.84 \\
(\mathrm{SD}=2.14)\end{array}$ & $\begin{array}{c}1.00 \\
(\mathrm{SD}=1.99)\end{array}$ & $\begin{array}{c}0.92 \\
(\mathrm{SD}=1.34)\end{array}$ \\
\hline $\begin{array}{l}\text { o citations } \\
\text { detected }\end{array}$ & $\begin{array}{c}335 \\
(46.85 \%)\end{array}$ & $\begin{array}{c}116 \\
(63.74 \%)\end{array}$ & $\begin{array}{c}1,454 \\
(50.95 \%)\end{array}$ & $\begin{array}{c}650 \\
(57.57 \%)\end{array}$ & $\begin{array}{c}795 \\
(35.62 \%)\end{array}$ & $\begin{array}{c}645 \\
(49.43 \%)\end{array}$ \\
\hline $\begin{array}{l}\text { I citation at } \\
\text { least detected }\end{array}$ & $\begin{array}{c}380 \\
(53.15 \%)\end{array}$ & $\begin{array}{c}66 \\
(36.26 \%)\end{array}$ & $\begin{array}{c}1,400 \\
(49.05 \%)\end{array}$ & $\begin{array}{c}479 \\
(42.43 \%)\end{array}$ & $\begin{array}{c}1,437 \\
(64.38 \%)\end{array}$ & $\begin{array}{c}660 \\
(50.57 \%)\end{array}$ \\
\hline 1-9 citation & $\begin{array}{c}320 \\
(44.75 \%)\end{array}$ & $\begin{array}{c}56 \\
(30.77 \%)\end{array}$ & $\begin{array}{c}1,106 \\
(38.75 \%)\end{array}$ & $\begin{array}{c}395 \\
(34.99 \%)\end{array}$ & $\begin{array}{c}1,294 \\
(57.97 \%)\end{array}$ & $\begin{array}{c}601 \\
(46.05)\end{array}$ \\
\hline 10-49 citations & $\begin{array}{c}41 \\
(5.73 \%) \\
\end{array}$ & $\begin{array}{c}9 \\
(4.95 \%) \\
\end{array}$ & $\begin{array}{c}229 \\
(8.02 \%) \\
\end{array}$ & $\begin{array}{c}66 \\
(5.85 \%) \\
\end{array}$ & $\begin{array}{c}117 \\
(5.24 \%) \\
\end{array}$ & $\begin{array}{c}54 \\
(4.14 \%) \\
\end{array}$ \\
\hline 50-99 citations & $\begin{array}{c}8 \\
(1.12 \%)\end{array}$ & $\begin{array}{c}0 \\
(0.00 \%)\end{array}$ & $\begin{array}{c}32 \\
(1.12 \%)\end{array}$ & $\begin{array}{c}12 \\
(1.06 \%)\end{array}$ & $\begin{array}{c}21 \\
(0.94 \%)\end{array}$ & $\begin{array}{c}5 \\
(0.38 \%)\end{array}$ \\
\hline$\geq 100$ citations & $\begin{array}{c}11 \\
(1.54 \%)\end{array}$ & $\begin{array}{c}1 \\
(0.55 \%)\end{array}$ & $\begin{array}{c}33 \\
(1.16 \%)\end{array}$ & $\begin{array}{c}6 \\
(0.53 \%)\end{array}$ & $\begin{array}{c}5 \\
(0.22 \%)\end{array}$ & $\begin{array}{c}0 \\
(0 \%)\end{array}$ \\
\hline
\end{tabular}

Source: BITRA (April 2017)

An analysis of the results of single and co-authored books in each period showed that the percentage of single-authored books decreases over time (1961-1980: 79.71\%; 1981-2000: 71.65\%; 2001-2015: 63.10\%), while the percentage of co-authored books increases (1961-1980: 20.29\%; 1981-2000: 28.35\%; 2001-2015: 36.90\%). The same pattern is found when analyzing the percentage of citations accrued by single and co-authored books in each period: the percentage of citations accrued by single-authored books decreases over time (1961-1980: 89.15\%; 1981-2000: 78.62\%; 2001-2015: 72.81\%), while the percentage accrued by co-authored books increases (1961-1980: 10.85\%; 1981-2000: 21.38\%; 2001-2015: 27.19\%).

A Kruskal-Wallis test indicated that there were statistically significant differences between time periods for single-authored books regarding the mean number of citations obtained $\left(H[2]=250.392 ; p<0.001 ; \eta^{2}=0.08\right)$. Statistically significant differences were found between the 1981-2000 and 2001-2015 periods $(U=677699.5 ; p<0.001$, Bonferroni corrected, $r=$ 0.33), but not between the $1961-1980$ and $1981-2000$ periods $(U=265941.5 ; p=0.999$, Bonferroni 
corrected, $r=0.01)$. In the case of co-authored books, after running a Kruskal-Wallis test ( $H[2]$ $\left.=109.313 ; p<0.001 ; \eta^{2}=0.09\right)$, a statistical difference was found between the 1981-2000 and 2001-2015 periods $(U=102461 ; p<0.001$, Bonferroni corrected, $r=0.35)$, but not between the 1961-1980 and 1981-2000 periods ( $U=15714.5 ; p=0.999$, Bonferroni corrected, $r=0.01)$.

A Man-Whitney U-test was run to determine if there were differences between types of authorship in the case of books. Differences were non-significant in all periods (1961-1980: $U$ $=12370.5 ; p=0.861, r=0.01$; 1981-2000: $U=331462 ; p=0.708, r=0.01 ; 2001-2015: U=459614 ; p=$ $0.255, r=0.03$ ) i.e., as far as books are concerned our results do not show a citation advantage for any specific authorship type.

Summarizing, there seems to be a descending trend in citing single-authored books when comparing the 1981-2000 and 2001-2015 periods, while in these same periods there seems to be an ascending trend in citing co-authored books. However, these trends are very subtle descriptively. To confirm this trend the same calculations should be carried out again when data for a longer citation window are available.

\subsubsection{Evolution of citation rates in the case of TS articles}

The total number of journal articles included in the period analyzed (1961-2015) is 29,083. The BITRA database has so far detected 26,344 citations for these documents, which means that articles have been cited on average 0.91 times each.

\section{TABLE 4}

Number and percentage of articles in citation intervals over time in relation to authorship type

\begin{tabular}{|c|c|c|c|c|c|c|}
\hline $\begin{array}{l}\text { YEAR SPAN \& } \\
\text { AUTHORSHIP } \\
\text { TYPE }\end{array}$ & $\begin{array}{l}\text { 1961-1980 } \\
\text { SINGLE- } \\
\text { AUTHORED }\end{array}$ & $\begin{array}{l}\text { 1961-1980 } \\
\text { CO- } \\
\text { AUTHORED }\end{array}$ & $\begin{array}{l}1981-2000 \\
\text { SINGLE- } \\
\text { AUTHORED }\end{array}$ & $\begin{array}{l}\text { 1981-2000 } \\
\text { CO- } \\
\text { AUTHORED }\end{array}$ & $\begin{array}{l}\text { 2001-2015 } \\
\text { SINGLE- } \\
\text { AUTHORED }\end{array}$ & $\begin{array}{c}\text { 2001-2015 } \\
\text { CO- } \\
\text { AUTHORED }\end{array}$ \\
\hline \# articles & $\begin{array}{c}2,132 \\
(94.46 \%)\end{array}$ & $\begin{array}{c}125 \\
(5.54 \%)\end{array}$ & $\begin{array}{c}9,623 \\
(89.38 \%)\end{array}$ & $\begin{array}{c}1,143 \\
(10.62 \%)\end{array}$ & $\begin{array}{c}12,989 \\
(81.54 \%)\end{array}$ & $\begin{array}{c}2,941 \\
(18.46 \%)\end{array}$ \\
\hline $\begin{array}{l}\text { \# citations } \\
\text { detected }\end{array}$ & $\begin{array}{c}1,826 \\
(94.56 \%)\end{array}$ & $\begin{array}{c}105 \\
(5.44 \%)\end{array}$ & $\begin{array}{c}11,709 \\
(89.94 \%)\end{array}$ & $\begin{array}{c}1,310 \\
(10.06 \%)\end{array}$ & $\begin{array}{c}9,025 \\
(79.21 \%)\end{array}$ & $\begin{array}{c}2,369 \\
(20.79 \%)\end{array}$ \\
\hline $\begin{array}{l}\text { Normalized } \\
\text { mean of } \\
\text { citations } \\
\text { per article }\end{array}$ & $\begin{array}{c}1.02 \\
(\mathrm{SD}=1.55)\end{array}$ & $\begin{array}{c}1.01 \\
(\mathrm{SD}=1.13)\end{array}$ & $\begin{array}{c}1.01 \\
(\mathrm{SD}=1.84)\end{array}$ & $\begin{array}{c}0.97 \\
(\mathrm{SD}=1.50)\end{array}$ & $\begin{array}{c}0.95 \\
(\mathrm{SD}=1.16)\end{array}$ & $\begin{array}{c}0.99 \\
(\mathrm{SD}=1.12)\end{array}$ \\
\hline $\begin{array}{l}\text { o citations } \\
\text { detected }\end{array}$ & $\begin{array}{c}1,357 \\
(63.65 \%)\end{array}$ & $\begin{array}{c}82 \\
(65.6 \%)\end{array}$ & $\begin{array}{c}5,847 \\
(60.76 \%)\end{array}$ & $\begin{array}{c}694 \\
(60.72 \%)\end{array}$ & $\begin{array}{c}8,924 \\
(68.70 \%)\end{array}$ & $\begin{array}{c}1,887 \\
(64.16 \%)\end{array}$ \\
\hline $\begin{array}{l}\text { I citation at } \\
\text { least detected }\end{array}$ & $\begin{array}{c}775 \\
(36.35 \%)\end{array}$ & $\begin{array}{c}43 \\
(34.4 \%)\end{array}$ & $\begin{array}{c}3,776 \\
(39.24 \%)\end{array}$ & $\begin{array}{c}449 \\
(39.28 \%)\end{array}$ & $\begin{array}{c}3,974 \\
(30.60 \%)\end{array}$ & $\begin{array}{c}1,054 \\
(35.84 \%)\end{array}$ \\
\hline
\end{tabular}




\begin{tabular}{lcccccc}
\hline 1-9 citation & $\begin{array}{c}745 \\
(34.94 \%)\end{array}$ & $\begin{array}{c}41 \\
(32.8 \%)\end{array}$ & $\begin{array}{c}3,528 \\
(36.66 \%)\end{array}$ & $\begin{array}{c}423 \\
(37.01 \%)\end{array}$ & $\begin{array}{c}3,857 \\
(29.69 \%)\end{array}$ & $\begin{array}{c}1,025 \\
(34.85 \%)\end{array}$ \\
\hline 10-49 citations & $\begin{array}{c}28 \\
(1.31 \%)\end{array}$ & $\begin{array}{c}2 \\
(1.60 \%)\end{array}$ & $\begin{array}{c}237 \\
(2.46 \%)\end{array}$ & $\begin{array}{c}25 \\
(2.19 \%)\end{array}$ & $\begin{array}{c}115 \\
(0.89 \%)\end{array}$ & $\begin{array}{c}29 \\
(0.99 \%)\end{array}$ \\
\hline $50-99$ citations & $\begin{array}{c}2 \\
(0.09 \%)\end{array}$ & $\begin{array}{c}0 \\
(0.00 \%)\end{array}$ & $\begin{array}{c}9 \\
(0.09 \%)\end{array}$ & $\begin{array}{c}1 \\
(0.09 \%)\end{array}$ & $\begin{array}{c}2 \\
(0.02 \%)\end{array}$ & $\begin{array}{c}0 \\
(0.00 \%)\end{array}$ \\
\hline 2 100 citations & 0 & 0 & 2 & 0 & 0 & 0 \\
$(0.00 \%)$ & $(0.00 \%)$ & $(0.02 \%)$ & $(0.00 \%)$ & $(0.00 \%)$ & $(0.00 \%)$ \\
\hline
\end{tabular}

Source: BITRA (April, 2017)

An analysis of the percentage of single and co-authored articles in each period showed that the percentage of single-authored articles decreases over time (1961-1980: 94.46\%; 1981-2000: 89.38\%; 2001-2015: 81.54\%), while the percentage of co-authored articles increases (1961-1980: 5.54\%; 1981-2000: 10.62\%; 2001-2015: 18.46\%). The same pattern is found when analyzing the percentage of citations accrued by single and co-authored articles in each period: the percentage of citations accrued by single-authored articles decreases over time (1961-1980: 94.56\%; 1981-2000: 89.94\%; 2001-2015: 79.21\%), while the percentage accrued by co-authored articles increases (1961-1980: 5.44\%; 1981-2000: 10.06\%; 2001-2015: 20.79\%).

A Kruskal-Wallis test indicated that there were statistically significant differences between time periods for single-authored articles regarding the mean number of citations obtained $\left(H[2]=242.470 ; p<0.001 ; \eta^{2}=0.03\right)$. These differences were found between the 1961-1980 and 1981-2000 periods $(U=1245958.5 ; p<0.001$, Bonferroni corrected, $r=0.15)$, and the 19812000 and 2001-2015 periods $(U=6012794.5 ; p<0.001$, Bonferroni corrected, $r=0.20)$. In the case of co-authored articles, after running a Kruskal-Wallis test $\left(H[2]=48.617 ; p<0.001 ; \eta^{2}=0.03\right)$, a statistically significant difference was found between the 1981-2000 and 2001-2015 periods $(U=184017.5 ; p<0.001$, Bonferroni corrected, $r=0.22)$, but not between the 1961-1980 and 19812000 periods $(U=8121.5 ; p=0.138$, Bonferroni corrected, $r=0.16)$.

A Mann-Whitney U-test was run to determine if there were differences between types of authorship in the case of articles. Differences were significant in the 2001-2015 period ( $U$ $=1976971 ; p<0.01, r=0.06)$, while they were not in the 1961-1980 period $(U=15979 ; p=0.644$, $r=0.04)$ and in the $1981-2000$ period $(U=829825.5 ; p=0.451, r=0.02)$ i.e., as far as articles are concerned our results show a slight citation advantage for co-authorship starting from 2001.

\subsubsection{Evolution of citation rates in the case of TS book chapters}

As far as book chapters are concerned, the period analyzed (1961-2015) comprises 25,688 documents altogether, for which 24,602 citations have been detected in BITRA so far (see table 5). Taking these data as a whole, the average citations per book chapter is 0.96 . 


\section{TABLE 5}

Number and percentage of books chapters in citation intervals over time in relation to authorship type

\begin{tabular}{|c|c|c|c|c|c|c|}
\hline $\begin{array}{l}\text { YEAR SPAN \& } \\
\text { AUTHORSHIP } \\
\text { TYPE }\end{array}$ & $\begin{array}{l}\text { 1961-1980 } \\
\text { SINGLE- } \\
\text { AUTHORED }\end{array}$ & $\begin{array}{c}\text { 1961-1980 } \\
\text { CO- } \\
\text { AUTHORED }\end{array}$ & $\begin{array}{l}\text { 1981-2000 } \\
\text { SINGLE- } \\
\text { AUTHORED }\end{array}$ & $\begin{array}{c}\text { 1981-2000 } \\
\text { CO- } \\
\text { AUTHORED }\end{array}$ & $\begin{array}{l}\text { 2001-2015 } \\
\text { SINGLE- } \\
\text { AUTHORED }\end{array}$ & $\begin{array}{c}\text { 2001-2015 } \\
\text { CO- } \\
\text { AUTHORED }\end{array}$ \\
\hline \# book chapter & $\begin{array}{c}786 \\
(96.32 \%)\end{array}$ & $\begin{array}{c}30 \\
(3.68 \%)\end{array}$ & $\begin{array}{c}8,814 \\
(89.38 \%)\end{array}$ & $\begin{array}{c}1,047 \\
(10.62 \%)\end{array}$ & $\begin{array}{c}12,927 \\
(86.12 \%)\end{array}$ & $\begin{array}{c}2,084 \\
(13.88 \%)\end{array}$ \\
\hline $\begin{array}{l}\text { \# citations } \\
\text { detected }\end{array}$ & $\begin{array}{c}1,876 \\
(95.33 \%)\end{array}$ & $\begin{array}{c}92 \\
(4.67 \%)\end{array}$ & $\begin{array}{c}12,042 \\
(89.23 \%)\end{array}$ & $\begin{array}{c}1,454 \\
(10.77 \%)\end{array}$ & $\begin{array}{c}7,620 \\
(83.39 \%)\end{array}$ & $\begin{array}{c}1,518 \\
(16.61 \%)\end{array}$ \\
\hline $\begin{array}{l}\text { Normalizedmean } \\
\text { of citations per } \\
\text { book chapter }\end{array}$ & $\begin{array}{c}1.07 \\
(S D=1.69)\end{array}$ & $\begin{array}{c}0.85 \\
(S D=1.41)\end{array}$ & $\begin{array}{c}1.02 \\
(S D=1.89)\end{array}$ & $\begin{array}{c}1.07 \\
(S D=1.69)\end{array}$ & $\begin{array}{c}1.07 \\
(S D=1.19)\end{array}$ & $\begin{array}{c}1.09 \\
(S D=1.48)\end{array}$ \\
\hline $\begin{array}{l}\text { o citations } \\
\text { detected }\end{array}$ & $\begin{array}{c}342 \\
(43.51 \%)\end{array}$ & $\begin{array}{c}6 \\
(20.00 \%)\end{array}$ & $\begin{array}{c}4,955 \\
(56.22 \%)\end{array}$ & $\begin{array}{c}593 \\
(56.64 \%)\end{array}$ & $\begin{array}{c}9,306 \\
(71.99 \%)\end{array}$ & $\begin{array}{c}1,347 \\
(64.64 \%)\end{array}$ \\
\hline $\begin{array}{l}\text { I citation at } \\
\text { least detected }\end{array}$ & $\begin{array}{c}444 \\
(56.49 \%)\end{array}$ & $\begin{array}{c}24 \\
(80.00 \%)\end{array}$ & $\begin{array}{c}3,859 \\
(43.78 \%)\end{array}$ & $\begin{array}{c}454 \\
(43.36 \%)\end{array}$ & $\begin{array}{c}3,621 \\
(28.01 \%)\end{array}$ & $\begin{array}{c}737 \\
(35.36 \%)\end{array}$ \\
\hline 1-9 citations & $\begin{array}{c}406 \\
(51.65 \%)\end{array}$ & $\begin{array}{c}23 \\
(76.67 \%)\end{array}$ & $\begin{array}{c}3,635 \\
(41.24 \%)\end{array}$ & $\begin{array}{c}430 \\
(41.07 \%)\end{array}$ & $\begin{array}{c}3,535 \\
(27.35 \%)\end{array}$ & $\begin{array}{c}724 \\
(34.74 \%)\end{array}$ \\
\hline 10-49 citations & $\begin{array}{c}35 \\
(4.45 \%)\end{array}$ & $\begin{array}{c}0 \\
(0.00 \%)\end{array}$ & $\begin{array}{c}215 \\
(2.44 \%)\end{array}$ & $\begin{array}{c}24 \\
(2.29 \%)\end{array}$ & $\begin{array}{c}86 \\
(0.67 \%)\end{array}$ & $\begin{array}{c}12 \\
(0.58 \%)\end{array}$ \\
\hline 50-99 citations & $\begin{array}{c}2 \\
(0.25 \%)\end{array}$ & $\begin{array}{c}1 \\
(3.34 \%)\end{array}$ & $\begin{array}{c}5 \\
(0.06 \%)\end{array}$ & $\begin{array}{c}0 \\
(0.00 \%)\end{array}$ & $\begin{array}{c}0 \\
(0.00 \%)\end{array}$ & $\begin{array}{c}1 \\
(0.05 \%)\end{array}$ \\
\hline$\geq 100$ citations & $\begin{array}{c}2 \\
(0.25 \%)\end{array}$ & $\begin{array}{c}0 \\
(0.00 \%)\end{array}$ & $\begin{array}{c}4 \\
(0.05 \%)\end{array}$ & $\begin{array}{c}0 \\
(0.00 \%)\end{array}$ & $\begin{array}{c}0 \\
(0.00 \%)\end{array}$ & $\begin{array}{c}0 \\
(0.00 \%)\end{array}$ \\
\hline
\end{tabular}

Source: BITRA (April 2017)

An analysis of the percentage of single and co-authored book chapters in each period showed that the percentage of single-authored book chapters decreases over time (1961-1980: 96.32\%; 1981-2000: 89.38\%; 2001-2015: 86.12\%), while the percentage of co-authored book chapters increases (1961-1980: 3.68\%; 1981-2000: 10.62\%; 2001-2015: 13.88\%), but not as much as journal articles. The same pattern is found when analyzing the percentage of citations accrued by single and co-authored book chapters in each period: the percentage of citations accrued by single-authored book chapters decreases over time (1961-1980: 95.33\%; 1981-2000: 89.23\%; 2001-2015: 83.39\%), while the percentage accrued by co-authored book chapters increases (1961-1980: 4.67\%; 1981-2000: 10.77\%; 2001-2015: 16.61\%), but again not as much as journal articles in the last period. Indeed, these increases in the percentage of co-authored book chapters and in the percentage of citations accrued by co-authored book chapters are the smallest ones within the publication types under analysis.

A Kruskal-Wallis test indicated that there were statistically significant differences among time periods for single-authored book chapters regarding the mean number of citations ob- 
tained $\left(H[2]=411.304 ; p<0.001 ; \eta^{2}=0.05\right)$. Statistically significant differences were found between the 1961-1980 and 1981-2000 periods $(U=814476.5 ; p<0.05$, Bonferroni corrected, $r=$ 0.04), and between the 1981-2000 and 2001-2015 periods ( $U=5120109.5 ; p<0.001$, Bonferroni corrected, $r=0.26)$. In the case of co-authored book chapters, after running a Kruskal-Wallis test $\left(H[2]=47.897 ; p<0.001 ; \eta^{2}=0.04\right)$, a statistically significant difference was found between the 1981-2000 and 2001-2015 periods ( $U=130407$; $p<0.001$, Bonferroni corrected, $r=0.22$ ), but not between the $1961-1980$ and $1981-2000$ periods $(U=4700.5 ; p=0.916$, Bonferroni corrected, $r=0.13)$. According to these data, we can affirm that book chapters accrued a higher mean of citations per document in the last period analyzed regardless of authorship type than in the previous periods.

A Mann-Whitney $U$-test was run to determine if there were differences between types of authorship in the case of book chapters. No statistically significant differences were found in any period (1961-1980: $U=4586 ; p=0.246, r=0.13$; 1981-2000: $U=834572.5 ; p=0.091, r=0.05$; 2001-2015: $U=1295722 ; p=0.182, r=0.03)$, i.e., as far as book chapters are concerned, our results do not show a citation advantage for any specific authorship type.

\subsection{International collaboration in Translation Studies}

International collaboration-understood as those publications signed by at least two authors working in different countries-increases citation rates in some disciplines. For instance, Fry et al. (2009: 31-32) state that, "[d]espite some disagreement, there is evidence that co-authorship gains more citations than single authored papers and collaboration with an author from another country increases it more." In this vein, a number of authors (Katz and Hicks, 1997; Narin and Whitlow, 1991; Goldfinch et al., 2003; Sooryamoorthy, 2009; Nomaler et al., 2013) also observed that international collaboration increases citation rates more than domestic collaboration. According to Rikken (2016), the median number of citations of research documents for the 23 countries analyzed in his study was always higher in the case of publications with international collaboration.

Van Raan (1998) shows in his case study that self-citation should not be considered as the only or even main explanation for the higher impact of international co-authorship. In his own words (Van Raan, 1998: 427):

International collaboration often implies a considerable 'broadening' of the audiences around the authors, enhanced by more intensive 'networking' which is characteristic for 'internationality' of research. Therefore it is reasonable to posit that a 'genuine' increase of impact, i.e., not based on self-citing strategies alone, will occur.

Therefore, it would be interesting to explore the behavior of TS scholars in this respect to find out whether there is also a positive citation advantage in the case of international collabora- 
tion. However, since the available TS databases do not provide information about the institutions scholars belong to, we will look for indirect evidence, through available data in journals.

We first consulted Scopus SJR 2016 h-index ${ }^{14}$, since it includes a relatively high number of TS journals (25\% of the total active journals according to RETI) fering both a journal ranking and data about international collaboration. We searched for the rates of international collaboration and h-index of the 32 TS journals included for 2012-2016 (see table 6) as this was the period that included data for most of the journals. Four journals were finally excluded because there were no data available for them ${ }^{16}$. We then consulted GSM h5-index, and the JIF in WoS, both for 2016. Triangulating data from three different sources enabled us to obtain a more general and complete picture of journals' impact, since these indexes complement each other.

\section{TABLE 6}

Ratio of international collaboration, SJR h-index, GSM h5-index and JIF in WoS of TS journals ${ }^{17}$

\begin{tabular}{|c|c|c|c|c|c|c|c|c|c|}
\hline & $\%$ IN & ERNAT & NAL CO & LABOR & ION & MEAN & SJR & GSM & JIF \\
\hline Journal & 2012 & 2013 & 2014 & 2015 & 2016 & $\begin{array}{l}2012- \\
2016\end{array}$ & 2016 & 2016 & 2016 \\
\hline Machine Translation & 40.00 & 33.33 & 42.86 & 33.33 & 66.67 & 43.23 & 20 & - & - \\
\hline Terminology & 16.67 & 20.00 & 25.00 & 18.18 & 0 & 15.97 & 18 & - & 0.476 \\
\hline $\begin{array}{l}\text { Interpreter and } \\
\text { Translator Trainer }\end{array}$ & 20.00 & 0 & 7.69 & 25.00 & 21.74 & 14.89 & 7 & 11 & 0.316 \\
\hline Target & 0 & 0 & 15.79 & 35.00 & 21.74 & 14.51 & 16 & 15 & 0.838 \\
\hline $\begin{array}{l}\text { New Voices in } \\
\text { Translation Studies }\end{array}$ & 0 & 15.38 & 12.50 & 22.22 & 14.29 & 12.88 & 3 & - & - \\
\hline $\begin{array}{l}\text { Translation and } \\
\text { Interpreting }\end{array}$ & 20.00 & 4.35 & 21.43 & 16.67 & 0 & 12.49 & 5 & - & - \\
\hline Interpreting & 9.59 & 0.00 & 9.09 & 20.00 & 20.00 & 11.74 & 18 & - & 0.421 \\
\hline $\begin{array}{l}\text { Across languages } \\
\text { and cultures }\end{array}$ & 6.67 & 7.14 & 13.33 & 15.38 & 14.29 & 11.36 & 9 & - & 0.148 \\
\hline Multilingua & 5.56 & 6.45 & 3.70 & 13.33 & 19.05 & 9.62 & 20 & 15 & 0.556 \\
\hline
\end{tabular}

14 SCimago Journal Rank (SJR) h-index is an indicator based on journal's number of articles (h) that have received at least h citations over the whole period.

15 See Biblioteca d'Humanitats. Universitat Autònoma de Barcelona (2018).

16 Those journals excluded were Íkala, Linguistica Antverpiensia, Mutatis Mutandis and Panace@.

17 Journals have been ordered according to their average percentage of international collaboration in descending order. 


\begin{tabular}{|c|c|c|c|c|c|c|c|c|c|}
\hline $\begin{array}{l}\text { Translation and } \\
\text { Interpreting Studies }\end{array}$ & 6.67 & 13.33 & 17.65 & 5.88 & 4.17 & 9.54 & 4 & - & 0.177 \\
\hline Babel & 8.00 & 8.70 & 9.09 & 10.00 & 8.82 & 8.92 & 6 & 6 & 0.082 \\
\hline Languages in contrast & 16.67 & 8.33 & 8.33 & 7.69 & 0 & 8.20 & 5 & - & - \\
\hline Perspectives & 8.57 & 7.89 & 0 & 15.52 & 4.26 & 7.25 & 9 & - & - \\
\hline $\begin{array}{l}\text { Translation and } \\
\text { Literature }\end{array}$ & 0 & 0 & 0.00 & 25.00 & 5.88 & 6.18 & 6 & 4 & - \\
\hline Lebende Sprachen & 0 & 5.56 & 0.00 & 6.25 & 18.75 & 6.11 & 2 & 3 & - \\
\hline Translation Review & 0 & 16.67 & 6.67 & 0 & 5.56 & 5.78 & 3 & 2 & - \\
\hline Interpreter's Newsletter & 12.50 & 0 & 14.29 & 0 & 0 & 5.36 & 3 & - & - \\
\hline Hermeneus & 18.08 & 0 & 0 & 0 & 0 & 3.62 & 1 & - & - \\
\hline Translation Studies & 0 & 7.41 & 6.45 & 2.63 & 0 & 3.30 & 7 & 10 & 0.289 \\
\hline Translator & 0 & 0 & 3.85 & 10.53 & 0 & 2.88 & 15 & 9 & 0.483 \\
\hline Sendebar & 0 & 0 & 0 & 9.90 & 0 & 1.98 & 2 & 4 & - \\
\hline Meta & 0 & 0 & 0 & 4.35 & 8 & 2.47 & 15 & 11 & - \\
\hline Skase & 0 & 0 & 0 & 0 & 10 & 2 & 2 & - & - \\
\hline InTRAlinea & 0 & 0 & 0 & 6.25 & 0 & 1.25 & 1 & - & - \\
\hline Quaderns & 0 & 5.56 & 0 & 0 & 0 & 1.11 & 4 & 6 & - \\
\hline Palimpsestes & 0 & 0 & 0 & 0 & 0 & 0 & 1 & - & - \\
\hline Trans & 0 & 0 & 0 & 0 & 0 & 0 & 1 & - & - \\
\hline Hermes & 0 & 0 & 0 & 0 & 0 & 0 & 8 & - & - \\
\hline Mean by year & 6.75 & 5.72 & 7.78 & 10.83 & 8.68 & 7.95 & & & \\
\hline
\end{tabular}

Source: Rovira-Esteva et al. (2017), SJR (2018), WoS (2018)

The data obtained from this sample show that the degree of international cooperation varies a great deal among journals. For instance, while three journals did not publish a single international collaboration article during the five years under study, in the case of Machine Translation this kind of collaboration accounts on average for more than $40 \%$ of published articles. One reason for these differences could be the respective scopes of these journals: although they are all related to TS, some tend to focus on very specific topics. For instance, it seems that scholars involved in machine translation research tend more towards international co-authorship than those studying literary translation. Rikken (2016) found that $43 \%$ of all papers published in the previous five years from different fields were written by international research teams, although this varied greatly from one country to another, ranging from $23 \%$ in Turkey to $63.6 \%$ in Singapore. If we take Rikken as a reference, the results obtained for TS from this sample are surprisingly low, since the average percentage of international collaboration for the 2012-2016 
period is $7.95 \%$ and only eight out of the $28(28.57 \%)$ TS journals included in the analysis feature a mean above the $10 \%$ threshold of international cooperation. In this same vein, Larivière et al. (2006: 526) state that the percentage of international collaboration in the Humanities for most countries is stagnant and very low, and that between 1998-2002 only China and Hong Kong had an international collaboration rate above 15\%. Rikken (2016) concludes that "[t] he nature and magnitude of collaboration vary from one discipline to another, and depend upon such factors as the nature of the research problem, the research environment, and demographic factors."

International collaboration in TS is still a more marginal phenomenon than in the Social Sciences and Humanities, where Larivière et al. (2015) found it accounted for $16.4 \%$ of all papers in 2011. A fairly optimistic conclusion that can be drawn from table 6 is that there seems to be a trend towards more international cooperation (rising from $6.75 \%$ in 2012 to $10.83 \%$ in 2015, but dropping again to $8.68 \%$ in 2016).

It is especially noteworthy that the journals with a higher international cooperation are not always listed in the top two quartiles of impact indexes, although 12 out of the 14 journals in the first two quartiles of international collaboration are also situated in one of the first two impact quartiles of at least one of the indexes included ${ }^{18}$. That is to say, despite the fact that with the data available it is difficult to assess if higher international collaboration rates correlate with a positive citation advantage, journals with a higher ratio of international co-authorship tend to be better ranked in international indexes. Translation Studies, The Translator and Meta would be the exceptions. Therefore, with these data a positive citation advantage of international collaboration in the form of higher academic impact of the journal cannot be proved.

The different research cultures associated with topics, kind of research (quantitative versus qualitative), countries of origin, language of publication or the degree of localism of the journal might well explain the differences observed between TS journals. It seems reasonable to believe that theoretical work generally produces papers with fewer co-authors than experimental or applied research. On the other hand, the resulting collaboration rates must be interpreted as being solely the output of journal articles, which are far from covering all the research outputs in our discipline. Finally, since in TS impact in terms of citations can only be expected to start being really visible at least five to six years after publication (Rovira-Esteva et al., forthcoming), the data available probably do not provide enough perspective on the matter. To be able to assess TS international cooperation, we need data gathered in a way that can be analyzed against other comparable disciplines. Therefore, more research is needed to get a broader picture of international collaboration practices in TS.

18 The quartiles have been calculated by ordering each one of the indexes in descending order and dividing the list of journals in two halves. 


\subsection{Most cited co-authored contributions in Translation Studies}

Since co-authorship per se does not yet seem to be the determining factor to achieve a higher percentage of citations in TS research outputs, we have attempted to discover what the most cited TS co-authored works had in common, constituting possible variables liable to attract colleagues' attention and citations. When queried about co-authored entries with 50 or more citations for the period of study, BITRA yielded 25 results, which are listed in table 7 according to their mean citations per year up to 2017 in descending order.

\section{TABLE 7}

TS co-authored publications with $\geq 50$ citations $^{19}$

\begin{tabular}{|c|c|c|c|c|c|c|}
\hline AUTHORS & TITLE & YEAR & $\begin{array}{c}\text { KIND OF } \\
\text { DOCUMENT }\end{array}$ & LANGUAGE & $\begin{array}{c}\# \\
\text { CITATIONS }\end{array}$ & $\begin{array}{c}\text { MEAN } \\
\text { CITS./ YEAR }\end{array}$ \\
\hline Hatim; Mason & $\begin{array}{l}\text { Discourse and } \\
\text { the Translator }\end{array}$ & 1990 & Book & English & 340 & 12.6 \\
\hline Hatim; Mason & $\begin{array}{l}\text { The Translator as } \\
\text { Communicator }\end{array}$ & 1997 & Book & English & 240 & 12 \\
\hline Reiss; Vermeer & $\begin{array}{l}\text { Grundlegung } \\
\text { einer allgemeinen } \\
\text { Translationstheorie }\end{array}$ & 1984 & Book & $\begin{array}{l}\text { German; } \\
\text { English; } \\
\text { Spanish; } \\
\text { Finnish }\end{array}$ & 317 & 9.6 \\
\hline $\begin{array}{l}\text { Díaz-Cintas; } \\
\text { Remael }\end{array}$ & $\begin{array}{l}\text { Audiovisual Translation: } \\
\text { Subtitling }\end{array}$ & 2007 & Book & English & 62 & 6.2 \\
\hline $\begin{array}{l}\text { Bassnett- } \\
\text { McGuire; Bielsa }\end{array}$ & $\begin{array}{l}\text { Translation in } \\
\text { Global News }\end{array}$ & 2008 & Book & English & 52 & 5.8 \\
\hline $\begin{array}{l}\text { Bassnett - } \\
\text { McGuire; } \\
\text { Trivedi (eds.) }\end{array}$ & $\begin{array}{l}\text { Post-colonial } \\
\text { Translation: Theory } \\
\text { and Practice }\end{array}$ & 1998 & Book & English & 109 & 5.7 \\
\hline $\begin{array}{l}\text { Bassnett- } \\
\text { McGuire; } \\
\text { Lefevere (eds.) }\end{array}$ & $\begin{array}{l}\text { Translation, History } \\
\text { and Culture }\end{array}$ & 1990 & Book & English & 149 & 5.5 \\
\hline Nida; Taber & $\begin{array}{l}\text { The Theory and Practice } \\
\text { of Translation }\end{array}$ & 1969 & Book & $\begin{array}{l}\text { English; } \\
\text { Spanish; } \\
\text { German; } \\
\text { French; } \\
\text { Chinese }\end{array}$ & 233 & 4.8 \\
\hline
\end{tabular}

19 One of the most cited co-authored books in TS is Stylistique Comparée du Français et de l'Anglais. Méthode de traduction by Vinay and Darbelnet with 375 citations detected and 6.6 mean citations per year. However, since it was published in 1958, it does not fall within our period of analysis. 


\begin{tabular}{|c|c|c|c|c|c|c|}
\hline PACTE & $\begin{array}{l}\text { Building a translation } \\
\text { competence model }\end{array}$ & 2003 & $\begin{array}{c}\text { Book } \\
\text { chapter }\end{array}$ & English & 61 & 4.4 \\
\hline $\begin{array}{l}\text { Tymoczko; } \\
\text { Gentzler (eds.) }\end{array}$ & Translation and Power & 2002 & Book & English & 65 & 4.3 \\
\hline $\begin{array}{l}\text { Shuttleworth; } \\
\text { Cowie }\end{array}$ & $\begin{array}{l}\text { Dictionary of } \\
\text { Translation Studies }\end{array}$ & 1997 & Book & English & 86 & 4.3 \\
\hline Neubert; Shreve & Translation as Text & 1992 & Book & English & 100 & 4 \\
\hline $\begin{array}{l}\text { Bassnett- } \\
\text { McGuire; } \\
\text { Lefevere }\end{array}$ & $\begin{array}{l}\text { Constructing Cultures. } \\
\text { Essays on Literary } \\
\text { Translation }\end{array}$ & 1998 & Book & English & 70 & 3.7 \\
\hline $\begin{array}{l}\text { Williams; } \\
\text { Chesterman }\end{array}$ & $\begin{array}{l}\text { The Map. A } \\
\text { Beginner's Guide to } \\
\text { Doing Research in } \\
\text { Translation Studies }\end{array}$ & 2002 & Book & English & 52 & 3.5 \\
\hline Olohan; Baker & $\begin{array}{l}\text { Reporting 'that' in } \\
\text { Translated English. } \\
\text { Evidence for } \\
\text { Subconscious Processes } \\
\text { of Explicitation }\end{array}$ & 2000 & $\begin{array}{l}\text { Journal } \\
\text { article; } \\
\text { Book } \\
\text { chapter }\end{array}$ & English & 55 & 3.2 \\
\hline $\begin{array}{l}\text { Delisle; } \\
\text { Lee-Jahnke; } \\
\text { Cormier (eds.) }\end{array}$ & $\begin{array}{l}\text { Terminologie de la } \\
\text { traduction = Translation } \\
\text { terminology }\end{array}$ & 1999 & Book & $\begin{array}{l}\text { French; } \\
\text { English; } \\
\text { Spanish; } \\
\text { German; } \\
\text { Galician; } \\
\text { Arabic; } \\
\text { Chinese; } \\
\text { Finnish; } \\
\text { Italian; } \\
\text { Dutch; } \\
\text { Polish; } \\
\text { Romanian; } \\
\text { Russian; } \\
\text { Turkish }\end{array}$ & 58 & 3.2 \\
\hline Ivarsson; Carroll & Subtitling & 1998 & Book & English & 57 & 3 \\
\hline $\begin{array}{l}\text { Gentile; Ozolins; } \\
\text { Vasilakakos }\end{array}$ & $\begin{array}{l}\text { Liaison Interpreting: } \\
\text { A Handbook }\end{array}$ & 1996 & Book & English & 61 & 2.9 \\
\hline $\begin{array}{l}\text { Seleskovitch; } \\
\text { Lederer }\end{array}$ & $\begin{array}{l}\text { Pédagogie raisonnée } \\
\text { de l'interprétation }\end{array}$ & 1989 & Book & $\begin{array}{l}\text { French; } \\
\text { English }\end{array}$ & 79 & 2.8 \\
\hline $\begin{array}{l}\text { Seleskovitch; } \\
\text { Lederer }\end{array}$ & $\begin{array}{l}\text { Interpréter pour } \\
\text { traduiré }\end{array}$ & 1984 & Book & French & 89 & 2.7 \\
\hline $\begin{array}{l}\text { Snell-Hornby; } \\
\text { Hönig; } \\
\text { Kussmaul; } \\
\text { Schmitt (eds.) }\end{array}$ & Handbuch Translation & 1998 & Book & German & 50 & 2.6 \\
\hline $\begin{array}{l}\text { Hönig; } \\
\text { Kussmaul }\end{array}$ & $\begin{array}{l}\text { Strategie der } \\
\text { Übersetzung. Ein Lehr- } \\
\text { und Arbeitsbuch }\end{array}$ & 1982 & Book & German & 81 & 2.3 \\
\hline
\end{tabular}




\begin{tabular}{|c|c|c|c|c|c|c|}
\hline $\begin{array}{l}\text { Luyken; Herbst; } \\
\text { Langham- } \\
\text { Brown; Reid; } \\
\text { Spinhof }\end{array}$ & $\begin{array}{l}\text { Overcoming Language } \\
\text { Barriers in Television: } \\
\text { Dubbing \& Subtitling for } \\
\text { the European Audience }\end{array}$ & 1991 & Book & English & 56 & 2.1 \\
\hline Hervey; Higgins & $\begin{array}{l}\text { Thinking Translation: } \\
\text { A Course in } \\
\text { Translation Method, } \\
\text { French - English }\end{array}$ & 1992 & Book & English & 52 & 2.1 \\
\hline $\begin{array}{l}\text { Harris; } \\
\text { Sherwood }\end{array}$ & $\begin{array}{l}\text { Translating as an } \\
\text { Innate Skill }\end{array}$ & 1978 & $\begin{array}{l}\text { Book } \\
\text { chapter }\end{array}$ & English & 57 & 1.5 \\
\hline
\end{tabular}

Source: BITRA (2017)

Out of the 25 co-authored publications with at least 50 citations, $22(88 \%)$ are available in English, four in French (16\%), five in German (20\%), and three in Spanish (12\%). It is important to note that the same publication is available in more than one language in quite a few cases. As far as document type is concerned, 22 (88\%) are books, three (12\%) are book chapters and one (4\%) has been published both as a journal article and as a book chapter. Not a single journal article is found among the top-25. Amongst the most cited jointly authored contributions, there are only five edited volumes (20\%) and in all cases they are topic-centered, i.e., highly homogeneous from a thematic point of view. Eight of them (32\%) can be considered to be textbooks, and no case studies are found, which confirms that generalist approaches tend to accrue more citations. From the point of view of the citation window, the most recent contribution dates back to 2008, followed by one published in 2007, whereas the rest are from 2003 or earlier. There are 13 entries from the 1990 and four from the 1980 s. Actually, there seems to be a certain correlation between the year of publication and the number of citations accrued, i.e., the older, the more citations. Generally speaking, these results coincide with those for all kind of publications (Franco Aixelá, 2013; Franco Aixelá and Rovira-Esteva, 2015) in the sense that books written around the 1990 and in English on general topics are the best candidates for accruing large numbers of citations in TS.

\section{Co-authorship beyond citation counts}

Beyond the potential benefits of co-authorship from a quantitative point of view, such as higher production and a likely positive citation advantage, we would also like to reflect upon the value of co-authorship from a more qualitative perspective.

Sharples (1999, cited in Hartley, 2008: 170) describes three main ways of proceeding with multiple authorship: parallel (division of labor, i.e., different people do different jobs), sequential (one author takes over the work at the point someone else has left it), and reciprocal (all the partners work together, mutually making adjustments to take account of each other's contributions). However, many tenure and promotion committees in the Humanities have 
not yet developed mechanisms for assessing and crediting collaborative work, partly because there is still a widespread belief that co-authoring means doing half the work, rather than a sense that all parties do all the work. In other words, sometimes parallel authorship is taken for granted, thus penalizing and discouraging other kinds of collaborative scholarship.

The issue of multi-authorship has also been addressed from the point of view of ethics, with charges of a proliferation of honorary, ghost, or guest authorship, which poses problems related to publication misconduct, particularly issues of (in)justice in attributing authorship, as endemic within the research community. Some claim authorship credit should be based only on substantial contributions to conception and design, analysis and interpretation of data, drafting the article or revising it critically for important intellectual content and final approval of the version to be published. Meanwhile, others claim that authorship should be extended to reviewers or even proof-readers and editors, who in one way or another might contribute with insightful or useful suggestions for improving the quality of the published output.

There are scholars (see Hartley, 2008: 169; Bahr and Zemon, 2000: 417) who claim that collaborative writing enhances quality, especially if papers are signed in alphabetical order (Joseph et al., 2005: 545). In the same vein, both Presser (1980) and Bahr and Zemon (2000: 412-3) report that collaborative articles not only require less revision, but also have a greater chance of being accepted for publication, assuming that it is because the quality of these articles is better. An advantage of co-authorship for Hartley (2008: 171-2) is that each author serves as an editor for the other and, as authors may have different psychological skills, these abilities can be pooled. In sum, if everyone does all the work, the contributions can be expected to be of better quality on average, since the resulting essays will already have undergone an internal peer-review prior to their submission. Besides adding a layer of internal peer review, academic cooperation can also expand the field by pairing expertise, especially when sharing and borrowing ideas from other disciplines.

Joint authorship also has positive social aspects that should be pointed out, such as increasing our network of contacts and alleviating professional isolation through intellectual companionship. Working with a colleague on a variety of tasks, sharing the writing, responding collectively to the referees, and correcting the proofs together can be mutually satisfying tasks. As Katz and Martin (1997: 15) put it, "the act of collaborating may be a source of stimulation and creativity." Last but not least, Nudelman and Landers (1972, cited by Katz and Martin, 1997: 6) suggested "that the total credit given by the scientific community to all the authors of a jointly authored paper is greater on average than the credit allocated to the author of a single-author paper." In other words, co-authorship seems to have the collateral effect of enhancing individual academic reputation. This no doubt can be explained by the unconsciously assumed better quality of co-authored papers.

Nevertheless, collaborative writing may also have disadvantages to be taken into account, especially when assessing it. Among the disadvantages, Hartley (2008: 172) men- 
tions that production can be slowed down if one colleague is overworked. Bahr and Zemon (2000: 416) comment that working together takes more time because co-authors must consult frequently throughout their project and spend extra time working out differences of opinion or approaches. As Bahr and Zemon (2000: 416) underline, these difficulties can increase with long-distance collaboration "because many aspects of the process are done more easily in person rather that at a distance." They further add: "[c]ollaboration always requires enormous give and take", where "the collaborators' individual efforts must be merged into a seamless paper that communicates in one consistent style and voice" (Bahr and Zemon, 2000: 417).

Since co-authorship practices vary greatly throughout disciplines and joint authorship does not mean or imply the same across disciplines, it is mandatory to know what the standard practices and current trends are within TS in order to adequately assign credit, accountability and responsibility. Our research so far suggests that this issue has been overlooked. In their exploratory study, Rovira-Esteva and Orero (2011: 240) concluded that in the corpus of TS journals they selected for their study, an alphabetical order was followed in slightly more than half of the cases (51.7\%). The data on author ordering from table 7 suggest a similar tendency. Therefore, it is our contention that authors within TS vary in their ways of collaborating according to who they collaborate with, as well as their methodologies and topics, but they are by default more likely to choose a collegiate or reciprocal form of collaboration, so that colleagues are often equal partners in the enterprise. Since to glean information about authorship credit from the order in which authors are listed can be misleading and drive us to unfair judgments, the rate of incidental alphabetical authorship should also be quantified for TS. For assessment purposes it would be advisable for authors to clearly footnote who contributed what, as well as the criterion followed in author ordering.

\section{Conclusions}

This article presents a bibliometric study on co-authorship in TS, which addresses the issue from both quantitative and qualitative perspectives. It has attempted to provide new data and insights into different aspects related to collaborative work in TS, which until now have been largely overlooked. Wherever data are available, results have been set into the broader context of neighboring disciplines to provide a meaningful picture of the situation.

We have addressed the research questions raised at the beginning and our data have yielded some interesting results. Firstly, we have shown that TS have their own ecosystem as far as co-authorship practices are concerned in relation to closely-related disciplines. In our corpus of over 64,000 TS publications, only $16 \%$ are co-authored. The average number of authors in TS publications has increased with time and is currently 1.3, while the average number of authors taking into account only co-authored documents is 2.6. This means that 2-3 is the usual number for co-authored documents in TS, with more authors being something 
quite exceptional. In relation to other neighboring disciplines, the percentage of co-authorship is higher, but not so the number of authors per document.

Secondly, the historical evolution of co-authorship in TS shows a clearly rising tendency, with a minimum of 7.4\% in the 1960's and a steady increase since then: 8.5\% (1971-80), 11.1\% (1981-90), 14.2\% (1991-2000), 19.9\% (2001-2010) and 25.1\% in the 21st century. Furthermore, a detailed analysis of the 21st century shows that this upward tendency is consistent. We have seen that the ratios of single-authored documents decrease over time, while the percentage of co-authored documents increases for all document types. At the same time, the percentage of citations accrued by single-authored documents also decreases over time, while the percentage accrued by co-authored documents increases. However, the percentage of single-authored documents and the percentage of citations accrued by this type of authorship are still larger than those of co-authored documents. It is necessary for research assessment purposes to keep monitoring this trend in the future.

Thirdly, co-authorship varies in relation to document type and journal. Co-authorship in TS is still not the norm, but nowadays one fourth of TS published works are co-authored. Books-probably due to the existence of conference proceedings-are the document type with a higher percentage of co-authored documents (27.8\%), followed by articles (11.2\%) and book chapters (9.0\%).

Fourthly, a positive co-authorship citation advantage has not been proved for TS documents as a whole. However, we have proved that generally speaking co-authorship is not a disadvantage for accruing more citations. Indeed, our data seem to indicate a trend towards a positive co-authorship citation advantage in the case of journal articles in the last period of analysis (2001-2015). To see if this trend consolidates, the same calculations should be carried out again when data for a longer citation window are available.

Fifthly, according to our data, international collaboration is a very marginal phenomenon in TS (below 10\% on average in the last few years), and a positive citation advantage of international collaboration in the form of higher scientific impact of the journals in question cannot be proved.

Finally, from a qualitative point of view, we have seen that collaboration allows for people with complementary skills and knowledge to join forces to solve problems. Working with others provides support, feedback as you go or someone to work through your ideas with, so it is harder to get blocked when collaborating. Therefore, the advantage of co-authoring is not only greater productivity and probably more citations-as has been proved in some disciplines-, which can increase overall visibility, but it also brings about the promotion of critical exchange and inter-disciplinarity. However, collaboration poses some significant challenges, such as distributing and managing work, negotiating points of view and conflicts, being more time-consuming, as well as assigning credit. 
This study represents an initial insight into the evolution and current status of co-authorship in TS, and hopefully it might prove inspiring and a valuable starting point for future research. However, it has a number of shortcomings and opens up new avenues of research. It needs to be followed up with complementary studies that touch upon aspects not covered here, such as the reasons explaining the large share of publications going uncited, kinds of collaboration, self-citing, the role of funding, collaboration within research groups, differences between intramural and inter-institutional national collaboration, on the one hand, and international collaboration, on the other. Research is also needed to investigate practices in different sub-disciplines within TS, ratio of submission success in relation to kind of authorship, or even to contribute new data to pioneering studies on citation and knowledge networks (see Grbić and Pöllabauer, 2008a; Pöchhaker, 1995 and 1998; Pym, 2007; Buzelin, 2005). Moreover, at present, there is a range of questions concerning co-authorship that can only be addressed on the basis of qualitative methods, including interviews, surveys, observations or discussion groups. This study has focused more on a quantitative approach that needs to be complemented with qualitative studies such as the ones carried out by Manton and English (2006) and Kumar and Ratnavelu (2016) for the fields of business and economics, respectively. This would shed light on issues such as motives for co-authorship, ethics, personal experiences and perceived gains and difficulties of collaborative writing.

Another important limitation of this study is the database which has been the main source of data used. Although BITRA has more than 69,000 records, only 10\% have been mined for TS citations. It needs to be pointed out that we have been working with a sample, which, albeit large, has some bias with respect to the entire BITRA database. As far as language of publication and topics represented are concerned, deviations are not noteworthy. However, citing sources show an over-representation of research carried out from 2006 onwards, of articles as document type, and of open access as kind of availability. These biases are explained not only for operative reasons (accessibility of documents and cost-effectiveness of the mining), but also for academic reasons, since it can be expected that scholars might be more interested in the citation trends of more recent research. Finally, it should also be noted that BITRA excludes authorial self-citing as a confounder in impact analysis, which might be a disadvantage for co-authored contributions.

In light of the above-mentioned results, we should reflect on the benefits and drawbacks of co-authorship to value the personal and academic gain if we engage in collaboration. Our findings are of particular policy relevance, since academic hiring and promotional bodies and funding agencies should take note of these new trends in publication patterns in TS. Otherwise, until co-authorship is considered positive per se and becomes a standard practice within TS, it will remain a risky endeavor for authors and hard to assess for evaluators. However, we believe the way to promote quality in TS research is to reward collaboration, not to punish it. A way for evaluation committees to move the field of TS forward would be to promote collaborative writing by not automatically dividing credit among authors, an unacceptable pol- 
icy based on disinformation and prejudice, but rather by assigning credit according to actual practices. Hopefully, this article will go some way towards shedding light on co-authorship practices within TS and promoting greater self-understanding in our discipline.

\section{References}

ANECA, 2015: "Méritos para obtener calificación "A" en la evaluación de la actividad investigadora en solicitudes de acreditación para titular de universidad, a los efectos de lo previsto en el Art. 13.2 del RD 1312/2007, modificado por el RD 415/2015" [http://www.mecd.gob.es/educacion-mecd/dms/mecd/servicios-al-ciudadano-mecd/catalogo/general/educacion/academia/ ficha/academia/meritos-a-tu-investigacion.PDF, consulted: 27 May 2018].

BaHR, Alice Harrison, and Mickey Zemon, 2000: "Collaborative Authorship in the Journal Literature: Perspectives for Academic Librarians Who Wish to Publish", College \& Research Libraries 61 (5), 410-419 [doi:10.5860/crl.61.5.410].

Biblioteca d'Humanitats. Universitat Autònoma de Barcelona, 2018: ReTI: Revistes dels estudis de Traducció i Interpretació: Indicadors de qualitat, Departament de Traducció, Interpretació i Estudis de l’Àsia Oriental [http://www.uab.cat/libraries/reti, consulted: 20 May 2018].

Buzelin, Helene, 2005: "Unexpected Allies: How Latour's Network Theory Could Complement Bourdieusian Analyses in Translation Studies", The Translator 11 (2), 193-218.

Candel-Mora, Miguel Angel, and Chelo Vargas Sierra, 2013: "An Analysis of Research Production in Corpus Linguistics Applied to Translation”, Procedia - Social and Behavioral Sciences 95, 317-324.

Cronin, Blaise, and Kara Overfelt, 1994: "Citation-Based Auditing of Academic Performance", Journal of the American Society for Information Science 45 (2), 61-72.

De Bellis, Nicola, 2009: Bibliometrics and Citation Analysis. From the Science Citation Index to Cybermetrics, Lanham, Maryland; Toronto; Plymouth, UK: The Scarecrow Press.

Delgado López-Cózar, Emilio, Alberto Martin-Martín, Juan Manuel Ayllón, and Enrique Orduña-Malea, 2016: "Co-Author Index" [http://www.coauthorindex.info, consulted: 20 May 2018].

Dong, Dahui, and Meng-Lin Chen, 2015: "Publication Trends and Co-Citation Mapping of Translation Studies between 2000 and 2015", Scientometrics 105, 1111-1128 [doi:10.1007/s11192-015-1769-1].

Esqueda, Marileide Dias, and Silvana Maria de Jesus, 2015: "Scientific and Technical Translation in Brazilian Journals: A Benchmark Literature Review”, New Voices in Translation Studies 13, 79-101. 
Franco AixelA, Javier, 2001-2018: "BITRA (Bibliography of Interpreting and Translation) Open-Access Database” [doi:10.14198/bitra].

Franco AixelÁ, Javier, 2010a: “Una Visión Global de Las Publicaciones Con Mayor Impacto en Teoría de La Traducción”, Letras 48, 229-252.

Franco AixelÁ, Javier: 2010b: "Un cálculo preliminar del impacto de las publicaciones de traducción e interpretación escritas originalmente en español” in Rafael López-CAmpos, Carmen Balbuena, and Manuela Álvarez (eds.): Traducción y modernidad. Textos científicos, jurídicos, económicos y audiovisuales, Córdoba: Universidad de Córdoba, 371-389.

Franco AixelA, Javier, 2012: "A critical overview of the Translation Studies journals published in Spain" in Isabel Garcí-IzQuierdo and Esther Monzo (eds.): Iberian Studies on Translation and Interpreting, Bern: Peter Lang, 339-361.

Franco AixelA, Javier, 2013: "Who's Who and What's What in Translation Studies: A Preliminary Approach" in Catherine Way, Sonia Vandepitte, Reine Meylaerts, and Magdalena Bartlomiejczyk (eds.): Tracks and Treks in Translation Studies, Amsterdam: John Benjamins, 7-28 [doi:10.1075/ btl.108.01aix].

Franco AixelA, Javier, and Sara Rovira-Esteva, 2015: "Publishing and Impact Criteria, and Their Bearing on Translation Studies: In Search of Comparability”, Perspectives. Studies in Translatology. Special Issue: Bibliometric and Bibliographical Research in Translation Studies 23 (2) [doi:10. 1080/0907676X.2014.972419].

Fry, Jenny, Charles Oppenheim, Claire Creaser, William Johnson, Mark Summers, Sonya White, Geoff Butters, Jenny Craven, Jill Griffiths, and Dick Hartley, 2009: "Communicating Knowledge: How and Why UK Researchers Publish and Disseminate Their Findings. Supporting Paper 4: Literature Review."

GILE, Daniel, 2015: "Analyzing Translation Studies with scientometric data: from CIRIN to citation analysis", Perspectives: Studies in Translatology 23 (2), 240-248.

Goldfinch, Shaun, Tony Dale, and Karl DeRouen, 2003: "Science from the Periphery: Collaboration, Networks and 'periphery Effects' in the Citation of New Zealand Crovm Research Institutes Articles, 1995-2000", Scientometrics 57, 321-337.

Grbić, Nadja, 2013: "Bibliometrics" in Handbook of Translation Studies. Volume 4, Amsterdam: John Benjamins, 20-24 [doi:10.1075/hts.4.bib2].

Grbić, Nadja, and Sonja Pöllabauer, 2008a: "An Author-Centred Scientometric Analysis of Daniel Gile's Oeuvre" in Gyde Hansen, Andrew Chesterman, and Heidrun Gerzymisch-Arbogast (eds.): Efforts 
and Models in Interpreting and Translation Research. A Tribute to Daniel Gile, Amsterdam: John Benjamins, 3-24 [doi:10.1075/btl.80.03grb].

Grbić, Nadja, and Sonja Pöllabauer, 2008b: "Counting What Counts: Research on Community Interpreting in German-Speaking Countries. A Scientometric Study”, Target 20 (2), 297-332.

Grbić, Nadja, and Sonja Pöllabauer, 2008c: "To Count or Not to Count: Scientometrics as a Methodological Tool for Investigating Research on Translation and Interpreting", Translation and Interpreting Studies 3 (1-2), 87-146.

HaRTley, James, 2008: Academic Writing and Publishing: A Practical Handbook, London: Routledge.

HARzING, Anne-Wil, 2010: "Citation Analysis across Disciplines: The Impact of Different Data Sources and Citation Metrics" [http://www.harzing.com/publications/white-papers/citation-analysis-across-disciplines, consulted: 20 May 2018].

HuAng, Mu-hsuan, and CHAng, Yu-wei, 2008: "Characteristics of Research Output in Social Sciences and Humanities: From a Research Evaluation Perspective", Journal of the American Society for Information Science and Technology 59 (11), 1819-1828.

JosePH, Joshy, 2014: "Additive Scholarship and Divisive Credits: The Case of Multiple Authors in Marketing Papers” [http://ssrn.com/abstract=2397157, consulted: 20 May 2018].

Joseph, Kissan, David N. Laband, and Vivek Patil, 2005: "Author Order and Research Quality", Southern Economic Journal 71 (3), 545-555.

Katz, J. Sylvan, and Ben R. Martin, 1997: "What Is Research Collaboration?", Research Policy 26 (1), 1-18 [doi:10.1016/S0048-7333(96)00917-1].

KatZ, J. Sylvan, and Diana HıCKS, 1997: "How Much Is a Collaboration Worth? A Calibrated Bibliometric Model”, Scientometrics 40 (3), 541-554.

KuLD, Lukas, and O'HAGAN, John, 2018: "Rise of multi-authored papers in economics: Demise of the ‘lone star’ and why?”, Scientometrics 114 (3), 1207-1225 [http://doi.org/10.1007/s11192-017-2588-3].

Kumar, Sameer, and Kuru Ratnavelu, 2016: "Perceptions of Scholars in the Field of Economics on Co-Authorship Associations: Evidence from an International Survey", PLOS ONE 11 (6), 1-18 [doi:10.1371/journal.pone.0157633].

Lariviėre, Vincent, Cassidy R. Sugimoto, Andrew Tsou, and Yves Gingras, 2015: “Team Size Matters: Collaboration and Scientific Impact since 1900", Journal of the Association for Information Science and Technology 66 (7), 1323-1332. 
Lariviėre, Vincent, Yves Gingras, and Éric Archambault, 2006: "Canadian Collaboration Networks: A Comparative Analysis of the Natural Sciences, Social Sciences and the Humanities", Scientometrics 68 (3), 519-533 [doi:10.1007/s11192-006-0127-8].

Leimu, Roosa, and Julia Koricheva, 2005: "Does Scientific Collaboration Increase the Impact of Ecological Articles?”, Bioscience 55 (5), 438-443.

LIANG, Linxin, and Mingwu Xu, 2016: "A Bibliometric Analysis of International Translation Studies: Based on Relevant Data (2009-2013)", Translation Review 94 (1), 52-64 [doi:10.1080/073748 36.2016.1143427].

Manton, Edgar J., and Donald E. English, 2006: "Reasons for Co-Authorship in Business Journals and the Extent of Guest or Gift Authorships”, Delta Pi Epsilon Journal 48 (2), 86-95.

Moody, James, 2004: "The Structure of a Social Science Collaboration Network: Disciplinary Cohesion from 1963-1999", American Sociological Review 69 (2), 213-239.

Narin Francis, K. Stevens, and Edith S. Whitlow, 1991: "Scientific Co-Operation in Europe and the Citation of Multinationally Authored Papers”, Scientometrics 21, 313-323.

Nomaler, Önder, Koen Frenken, and Gaston Heimeriks, 2013: “Do More Distant Collaborations Have More Citation Impact?", Journal of Informetrics 7 (4), 966-971 [doi:10.1016/j.joi.2013.10.001].

Nouraey, Peyman, and Amin Karimnia, 2015: "The Map of Translation Studies in Modern Iran: An Empirical Investigation”, Asia Pacific Translation and Intercultural Studies 2 (2), 123-138 [doi:1 0.1080/23306343.2015.1059009].

Pérez-Paredes, Pascual, 2016: “La penalización de la multiautoría en la investigación en lingüística aplicada en España" [doi: 10.13140/RG.2.1.1978.7285].

PöchHaker, Franz, 1995: “'Those who do....: A Profile of Research(ers) in Interpreting”, Target 7 (1), $47-64$.

PöchHaker, Franz, 1998: "Unity in Diversity: The Case of Interpreting Studies" in Lynne Bowker, Michael Cronin, Dorothy Kenny, and Jennifer PeArson (eds.): Unity in Diversity? Current Trends in Translation Studies, Manchester: St. Jerome, 169-176.

Presser, Stanley, 1980: "Collaboration and the Quality of Research", Social Studies of Science 10 (1), 95-101.

Pym, Anthony, 2007: "Cross-Cultural Networking: Translators in the French-German Network of Petites Revues at the End of the Nineteenth Century", Meta 52 (4), 744-762 [doi: 10.7202/017695]. 
RIKKEN, Maarten, 2016: "Insights into International Research Collaboration”, Research Gate [https://www.researchgate.net/blog/post/insights-into-international-research-collaboration, consulted: 20 May 2018].

Rovira-Esteva, Sara, and Pilar Orero, 2011: "A Contrastive Analysis of the Main Benchmarking Tools for Research Assessment in Translation and Interpreting: The Spanish Approach", Perspectives. Studies in Translatology 19 (3), 233-251 [doi:10.1080/0907676X.2011.590214].

Rovira-Esteva, Sara, and Pilar Orero, 2012: "Evaluating Quality and Excellence in Translation Studies Research: Publish or Perish, the Spanish Way”, Babel 58 (3), 264-288.

Rovira-Esteva, Sara, Javier Franco AixelA, and Christian Olalla-Soler, forthcoming: "Citation patterns in Translation Studies: a format-dependent bibliometric approach."

Rovira-Esteva, Sara, Pilar Orero, and Javier Franco AixelA, 2015: "Bibliometric and Bibliographical Research in Translation Studies", Perspectives. Studies in Translatology. Special Issue: Bibliometric and Bibliographical Research in Translation Studies 23 (2) [doi:10.1080/090767 6X.2015.1026361].

Rovira-Esteva, Sara, Raúl Coré, Ana Lopo, and Montserrat Varona, 2017: "H-Index of Translation and Interpreting Journals according to Google Scholar Metrics (2012-2016)”, DTIEAO-BH Working Papers, 9 [https://ddd.uab.cat/record/181105, consulted: 20 May 2018].

SCImago Journal \& Country Rank (SJR), 2018: http://www.scimagojr.com/.

SOoryamoorthy, Radhamany, 2009: "Do Types of Collaboration Change Citation? Collaboration and Citation Patterns of South African Science Publications", Scientometrics 81 (1), 177-193 [doi:10.1007/s11192-009-2126-z].

Van Doorslaer, Luc, 2014: "Knowledge Structuring in Translation Studies", Innovative Infotechnologies for Science, Business and Education 1 (16), 22-25.

Van Doorslaer, Luc, 2016: "Bibliometric Studies" in Claudia V. Angelelli and Brian James Baer (eds.): Researching Translation and Interpreting, London and New York: Routledge, 168-176.

Van RaAn, Anthony F. J., 1998: "The Influence of International Collaboration on the Impact of Research Results”, Scientometrics 42 (3), 423-428 [doi:10.1007/BF02458380].

Waltman, Ludo, 2016: "A Review of the Literature on Citation Impact Indicators", Journal of Informetrics 10 (2), 365-391 [doi:doi.org/10.1016/j.joi.2016.02.007].

WANG, Binhua, 2013: "Describing the Progress of Interpreting Studies in China: A Bibliometrical Analysis of CSSCI / CORE Journal Articles during the Past Five Years", Translatio 32 (3), 115-126. 
Wang, Binhua, 2015: "A Bibliometrical Analysis of Interpreting Studies in China. Based on a Database of Articles Published in the CSSCI/CORE Journals in Recent Years", Babel 61 (1), 62-77 [doi:10.1075/babel.61.1.04wan].

Web of Science, 2018.

Wouters, Paul, Mike Thelwall, Kayvan Kousha, Ludo Waltman, Sarah de Rijcke, Alex Rushforth, and Thomas Franssen, 2015: The Metric Tide. Literature Review (Supplementary Report I to the Independent Review of the Role of Metrics in Research Assessment and Management), HEFCE.

Xu, Ziyun, 2015: "Doctoral Dissertations in Chinese Interpreting Studies. A Scientometric Survey Using Topic Modeling”, Forum 13 (1), 131-165 [doi:10.1075/forum.13.1.07xuz].

\section{Acknowledgements}

This article has been partially funded by the Catalan Government (2017 SGR113) and the Department of Translation, Interpreting and East Asian Studies of the Autonomous University of Barcelona. 